\title{
Creating a sustainable supply chain network by adopting relationship management strategies
}

\begin{abstract}
Purpose: This paper develops a conceptual framework to analyse the impact of a supply chain network (SCN) structure on relationship management strategies (RMS) that focal firms apply to manage sustainability issues within the SCN.

Design/methodology/approach: This paper is based on a comprehensive review and analysis of the industrial marketing and purchasing (IMP), sustainable supply chain management (SSCM), and SCN literature.
\end{abstract}

Findings: The conceptual framework expands the network perspective in the SSCM context by considering the important role of the SCN structure in the firm's decision-making process. Four factors (dependency, distance, power, and transparency) were found that are useful in conceptualising the SCN structure. The conceptual framework also categorises various sustainability practices into four RMS (non-compliance, transactional, dictatorial, and collaborative), which are needed to make a SCN more sustainable. In addition, 16 propositions are developed based on how firms may identify the most effective RMS to implement appropriate sustainability practices through examining their SCN structure.

Research limitations/implications: The conceptual framework, developed as a result of a comprehensive review of the literature, led to the development of 16 propositions, which can assist in furthering a research agenda on RMS to diffuse various sustainability practices within SCN structures.

Originality/value: The relationship between SCN structure and RMS in the sustainability context remains an under-researched but emerging area of interest. This paper leverages existing research to develop a conceptual framework suitable for empirical testing.

Keywords: Supply chain network structure, sustainable supply chain management, relationship management strategies, industrial marketing relationships, sustainability practices 


\section{Introduction}

In recent years, incorporating sustainable development objectives into the supply chain management (SCM) context has become an important topic among numerous researchers (Beske-Janssen, Johnson and Schaltegger 2015; Dubey, Gunasekaran and Papadopoulos 2017). The driving force for the interest is the mounting pressure from various stakeholders such as government regulators, community activists, and customers who expect more commitment to sustainability issues from firms (Abbasi 2017). The reason for this pressure is may related to the difficulties for end-customers to distinguish between the sustainability standards of the focal firms and their supply chain players (Roberts, 2003). In this regard, many firms have been redesigning their processes in terms of sustainable development objectives and employing various sustainability practices to enhance their brand and increase their competitive advantage (Dubey, Gunasekaran and Papadopoulos 2017; Kotler 2011; Mariadoss, Tansuhaj and Mouri 2011; Sharma et al. 2010).

Since demand and supply interactions do not only occur between two isolated parties (Rowley 1997), it is more realistic to look at supply chains (SC) from a network perspective. This recognises that the relationships between actors across the SC are not linear, rather, they can be understood as a web of direct and indirect relationships between various actors in a supply chain network (SCN) (Miemczyk, Johnsen and Macquet 2012). This development is inspired by the work of the industrial marketing and purchasing (IMP) group (Ford and McDowell 1999; Håkansson and Snehota 1995; Mattsson 1997; Ritter, Wilkinson and Johnston 2004). The industrial marketing relationship considers all activities that establish, develop, and maintain successful relational exchanges (Chu, Chang and Huang 2011), and has been extended via marketing research to a whole set of stakeholders rather than focusing only on the consumer in the business network (Svensson et al. 2016). Sharma et al. 2010 argue that some firms have been mainly focused on targeting the environmentally-conscious consumers while others concentrated on their marketing role in the SCM context. Marketing scholars also identify that "individual relationships are embedded in a context of other relationships that could have governance implications" (Heide 1994, 81). This means the network's structure can be shaped by the actions of numerous network actors (Kilduff and Tsai 2003; Heide 1994; Wuyts and Van den Bulte 2012). For example, governance can be defined as the explicit and 
implicit exchange rules in the relationship between two economic parties (Ghosh and John 2005), and can be varied from strong relations (e.g., joint venture) to weak relations (e.g., marketing alliances) (Hannah and Griffith 2012). Furthermore, managing sustainability issues within the SCM context includes a set of standards and practices that use the SC as a channel to influence the social and environmental status of the manufacturing and consumption process. The network perspective, therefore, provides information to better understand the sustainable development concept beyond a firm's boundaries (Kaneberg, Hertz and Jensen 2016; Miemczyk, Johnsen and Macquet 2012; Touboulic and Walker 2015), and has been considered as a high interest area by numerous researchers (Frostenson and Prenkert 2015; Meinlschmidt, Schleper and Foerstl 2018; Roscoe, Cousins and Lamming 2016; Wilhelm et al. 2016b).

In response to the increasing pressure, a growing number of large firms have attempted to employ various sustainability practices within their SCN (Dubey et al. 2017; Wilhelm et al. 2016a). Due to the vast resources these firms have, researchers often refer to them as focal firms in the business sustainability which may be necessary to institutionalise the sustainability agenda in the SCN (Glover et al. 2014). However, finding appropriate types of sustainability practices, which relate to different types of business relationships, is a challenging task (Grimm, Hofstetter and Sarkis 2016; Meinlschmidt, Schleper and Foerstl 2018). Typically, focal firms are embedded in an extended network environment, which consists of various SCN actors (such as suppliers, manufacturers, customers) who are often interrelated. The power balance, for example, between suppliers and retailers can affect the quality of the relationships between them (Mysen, Svensson and Högevold 2012), which can affect the types of sustainability practices in the SSCM context (Tachizawa and Wong 2014). Accordingly, the position of the actors and the pattern of interactions among them within the SCN structure can affect the implementation of the sustainability practices chosen by the focal firms (Touboulic and Walker 2015; Meinlschmidt, Schleper and Foerstl 2018).

Many studies have identified the significant impact of the SCN structure on a firm's strategic actions with respect to incorporating sustainability practices into its SCN (Frostenson and Prenkert 2015; Meinlschmidt, Schleper and Foerstl 2018; Miemczyk, Johnsen and Macquet 2012; Roscoe, Cousins and Lamming 2016; Tachizawa and Wong 2014; Wilhelm et al. 2016b). However, there is still a strong need to explore different aspects of SCN structure within the 
SSCM context (Meinlschmidt, Schleper and Foerstl 2018; Wilhelm et al. 2016b). Therefore, regarding the impact of the SCN structure on the adoption of sustainability practices and consequently the types of relationships chosen by the focal firms to manage sustainability issues, the next section explains how SCN theory provides a holistic view within a SCM context. Then, by providing the network perspective, the subsequent section describes how focal firms can improve sustainability in their SCN. This is followed by an explanation of how a SCN structure affects the decision process in focal firms with respect to managing sustainability issue within their SCN. Next, a conceptual framework is developed to assist focal firms to decide which types of RMS are appropriate to implement sustainability practices and is followed by suggesting propositions. In the last section, managerial implications, limitations and suggestions for future research are discussed.

\section{Supply chain network theory}

Networks are a "living, ever-changing organism" (Ritter, Wilkinson and Johnston 2004, 180) and a firm's ability to manage networks can affect its performance and development (Ritter and Gemünden 2003). At the network level, analysing the SCM practices goes beyond the organisation's boundaries, as the advancement of the internet tools and their integration with business communication (Lichtenthal and Eliaz 2003) facilitate the implementation of business buyer relationship management (Lichtenthal 2004). Network level analysis, stemming from network theory (which considers the whole of network perspective (Provan, Fish and Sydow 2007; Tracey, Heide and Bell 2014)), has been applied in the stakeholder literature to consider the multiple numbers of stakeholders, including suppliers, competitors, customers, nongovernmental organisations (NGO) and government bodies, and their relationships with each other (Miemczyk, Johnsen and Macquet 2012). Investigation of interrelationships between various actors within a network and analysis of their behaviours based on positional power are not typically considered by the dyadic and linear level of analysis (Miemczyk, Johnsen and Macquet 2012). Dyads are concerned with relationships between only two parties, and a focal dyad is related to any exchange relationship between two parties which is under investigation (Achrol, Reve, and Stern 1983). This type of relationship considers a focal firm as being the centre of its stakeholders and analyses the influences that various stakeholders (such as suppliers and customers) exert on the firm in a dyadic interaction (Miemczyk, Johnsen and 
Macquet 2012). The linear level includes the type of relationship that a firm indirectly develops through another firm, such as the indirect relationships between a firm and its second or more tier customers/suppliers (Anderson, Håkansson and Johanson 1994). The relationship at the connected-relations level has been analysed by Braziotis et al. (2013) as being multiple customer-supplier relationships, starting from extracting raw material to delivering final goods. From the connected relations' perspective, the structure of the flows in the SCM context is realised as a linear system in which managers usually focus on managing goods and materials that are vertically delivered between various organisations (Zuo, Kajikawa and Mori 2016). However, from a network perspective, the firms tend to pay attention to the various stakeholders within the SCM context rather than the firms who are directly active in the process of producing a product (Roome 2001) as the firms are dependent upon their network (Griffith and Harvey 2004). The network perspective is a vital component to fully understand the nature of dyadic relationships (Wathne and Heide 2004). For example, buying firms can create a buying group or a buying consortium (e.g., ProGroup in hardware industry), which can be considered a major force for other actors in the SCN (Geyskens, Gielens and Wuyts 2015). Wuyts and Dutta (2014) refer to this perspective as alliance portfolios that can have various consequences in the market (e.g., effects on superior product innovation). This is important, as there is a growing awareness in the business environment emphasising the importance of having effective and efficient network relationships within various business practices (e.g., new product development (NPD) in marketing practices (Achrol and Kotler 1999; Tracey, Heide and Bell 2014; Wuyts and Van den Bulte 2012)) which can lead to a competitive advantage (Addo-Tenkorang et al. 2017).

Incorporating the term, "network" into the SCM context indicates an attempt to provide a wider and more strategic view by utilising various potential resources of network actors in a more effective manner (Jin and Edmunds 2015). The network perspective questions the notion of applying the linear and one-dimensional approach to the SC by arguing the issues of relational aspects from a distinctive fixed position in the SC (Frostenson and Prenkert 2015). It also reflects the pattern of focal firms' relationships with their partners' partners and also third parties within the business network context (Wuyts and Geyskens 2005). In addition, there is a growing awareness within industrial marketing relationships to analyse the markets from an 
inter-organisational view rather than a discrete one (Homburg and Kuester 2001). For example, marketing decisions can be challenging in technology-intensive markets (John, Weiss, and Dutta 1999). Firms can facilitate the accessibility to the state of the art technologies and also market their new products by creating alliance networks within the high technology industries (Wuyts, Dutta, and Stremersch 2004). Understanding these new technologies and applying them to RMS is essential, particularly in choosing the different international market entry (IME) strategies. Further discussion about the different taxonomy of IME strategies, can be found in the extensive literature conducted by Watson et al. (2018). The relational viewpoint emanates from the notion that resources are distributed to the various entities within the business context. To create value for the customers, firms need to interact with other firms to have access to various resources which are out of their immediate control (Frostenson and Prenkert 2015). Therefore, understanding the firms' position and their relationship with various actors in the network perspective is a crucial step in developing appropriate types of strategic decisions (Cheng and Holmen 2015; Srinivasan, Wuyts and Mallapragada 2018).

\section{Sustainability issues in the supply chain network}

Based on the various definitions of sustainable supply chain management (SSCM), it seems essential that the unit of analysis in the SSCM needs to be analysed through an interorganisational network, which includes various types of actors at the macro-environmental level (Matthews et al. 2016). This is important as the sustainability issues in the extended network have a significant impact on a firm's business performance (Shokri Kahi et al. 2017). By looking at the SSCM from the network perspective, a sustainable supply chain network (SSCN) can be defined as a set of actors who work together to create a "sustainable circular economy" through considering the potential for social and environmental issues across the various stages of the product life cycle (Winkler 2011, 244). Firms typically consider the broad network of actors when attempting to ensure that stakeholders' expectations about sustainable development objectives are met (Ferro et al. 2017). The benefit of adopting this perspective is that some actors are able to compensate for others in the network, thus enabling the firm to meet its sustainable development objectives (Miemczyk, Johnsen and Macquet 2012). This means that the achievement of sustainability can occur through involving multiple 
interconnected actors who may themselves have different objectives (Araujo and Harrison 2002).

A SSCN can be considered a cornerstone of firms' sustainable development strategies, and developing such a sustainable network needs firms to evaluate their SCN actors with the improvement of social and environmental aspects (Snabe 2009). However, achieving sustainable development objectives in the SCN needs a key actor, which has sufficient resources to play a lead role (Alvarez, Pilbeam and Wilding 2010). This is mainly because they have more capabilities to systematically pursue the sustainability issues in the extended network (Elg and Hultman 2011). In most cases, the focal firm refers to the core actor who is driving sustainability in the SCM context (Beske-Janssen, Johnson and Schaltegger 2015). In the SSCM context, Seuring and Müller $(2008,1699)$ defined focal firms as "those firms that usually (1) rule or govern the supply chain, (2) provide the direct contact to the customer, and (3) design the product or service offered". In pursuing sustainable development objectives, focal firms have realised that managing sustainability issues in this context, which includes only their immediate SCN actors may not be effective (Tachizawa and Wong 2014). End customers are more likely to attribute the accountability of the sustainability issues to the focal firms, even though they may not have sufficient influence over their SCN actors (Hartmann and Moeller 2014). Therefore, focal firms seem to be the appropriate starting point to follow up on sustainability issues in their SCN (Beske-Janssen, Johnson and Schaltegger 2015).

The task of applying the particular types of relationships, which includes specific types of sustainability practices, is quite challenging as all RMS are not equally effective (Zhang et al. 2016). This is also important as the wrong type of relationships can be a source of tension between firms (Prince et al. 2016). Sustainability practices in firms cannot be developed in isolation, but instead, the various actors' characteristics (both upstream and downstream in the SC) (Awaysheh and Klassen 2010) and the interactions among multiple stakeholders (Parmigiani, Klassen and Russo 2011) need to be considered in the development of sustainability practices. As a firm's behaviour is highly dependent on the structure of interactions it has with the other actors in the network (Ritter, Wilkinson and Johnston 2004), it suggests it may be beneficial to analyse the SCN structure and determine how it can affect the firm's behaviour and strategy to manage sustainability practices. 
The impact of supply chain network structure on relationship management strategies to manage sustainability issues

As the SCN environment is complex, it is not easy for the focal firm to take strategic actions to achieve competitiveness unless it analyses the SCN in the way in which the SCN operates (Ekanayake, Childerhouse and Sun 2017). As Snehota and Hakansson $(1995,18)$ stated over two decades ago, "as managerial action is guided by how situations are framed, the relationship perspective and the network approach are unquestionably of consequence to management". A SCN consists of interrelated firms that are involved in various activities from extracting the raw materials to delivering the final product to the end-customer (Harland et al. 2001). It is then essential to analyse the influences the various SCN actors have on the focal firm's processes of determining a governance mechanism to be incorporated into the different types of relationships (Pullman et al. 2017), which can ultimatly lead to the sustainability practices. However, a range of research has considered governance mechanisms in the context of dyadic relationships which needs to be promoted to a wider context as there are different patterns of multiple relationships within the marketing exchange (Hutt, Reingen, and Ronchetto 1988; Kumar, Heide, and Wathne 2011; Palmatier, Scheer, and Steenkamp 2007). Wathne and Heide $(2004,73)$ for example, point out that a firm's governance response in a dyadic relationship is highly affected by its "immediate network context". Furthermore, the focal firms' expectation of achieving a specific outcome in sustainability performance is mainly related to the types of relationships with the various actors in the SCN (Roscoe, Cousins and Lamming 2016). For example, Roscoe, Cousins and Lamming (2016) argue that to develop eco-innovations (that is, innovation that improves environmental performances) that lead to improving the sustainability performance in the SCN, the focal firms need various types of relationships, including the building of weak relationships with multiple small actors and other actors that bridge 'structural holes' and build strong relationships with the strategic actors in the network. On the basis of a review of SSCM studies, Seuring (2011) identifies that focal firms usually engage with their suppliers to help them improve their business processes by providing a win-win situation with respect to sustainability issues. This closeness can also increase the effectiveness of relationships by, for example, controlling opportunism within the relationships (Wathne and Heide 2000; Wuyts and Geyskens 2005) which in turn may result in a loss of future contracts for the opportunistic actors (Houston and Johnson 2000). However, it is not clear how focal 
firms identify which actors in their SCN are strategic and which actors, for example, bridge the structural hole based on the pattern of interactions among the various SCN actors. Similarly, Wuyts and Van den Bulte (2012) argue that there is a gap in the marketing literature in terms of analysing the network governance effects and identifying the impact of network structure on the firms' behaviour. This is also important because, for example, the marketing literature has a tendency to only focus on the end-consumer, however, instead, it should be extended to the whole set of stakeholders in the business network context (Svensson et al. 2016). Thus, it is of interest to examine the network structure of SC interactions (Addo-Tenkorang et al. 2017).

Over the last decade there still appears to be little guidance for focal firms on the various types of network governance mechanisms and the factors that can affect these mechanisms in the literature (Van den bulte 2010; Van den bulte and wuyts 2007). Particularly, several sustainability frameworks have been introduced over the past ten years to help focal firms to choose effective RMS through various governance mechanisms and a set of sustainability practices in the SCN (Awaysheh and Klassen 2010; Crespin-Mazet and Dontenwill 2012; Kumar et al. 2017; Meinlschmidt, Schleper and Foerstl 2018; Parmigiani, Klassen and Russo 2011; Tachizawa and Wong 2014; Vachon and Klassen 2006; Vurro, Russo and Perrini 2009). All these researchers see the SCN structure as a key factor in the effective implementation of sustainability practices in the SCN. However, they have not clearly explained how the SCN structure can play a role in improving sustainability in the SCN. In the next section, a conceptual framework is developed to potentially fill the gap that focuses on deciding effective RMS in which appropriate types of sustainability practices need to be implement in the SCN.

\section{Towards a conceptual framework for sustainable supply chain networks}

Focal firms need to develop different RMS to implement sustainability practices its SCN based on the SCN structure. These strategies can be defined as behaviour and thoughts in which focal firms categorise their set of sustainability practices. A conceptual framework has been designed (Figure 1) to fully exploit the potential of the existing pattern of interactions among SCN actors in order to make a focal firm's SCN more sustainable. This model suggests that focal firms can incorporate sustainability practices into its SCN based on the various types of RMS. In addition, considering the SCN structure as being a critical factor (for the process of implementing sustainability practices) can help focal firms identify effective RMS (which 
includes a set of specific sustainability practices) to improve sustainability in their SCN. Various components of the conceptual framework will be explained in the following sections.
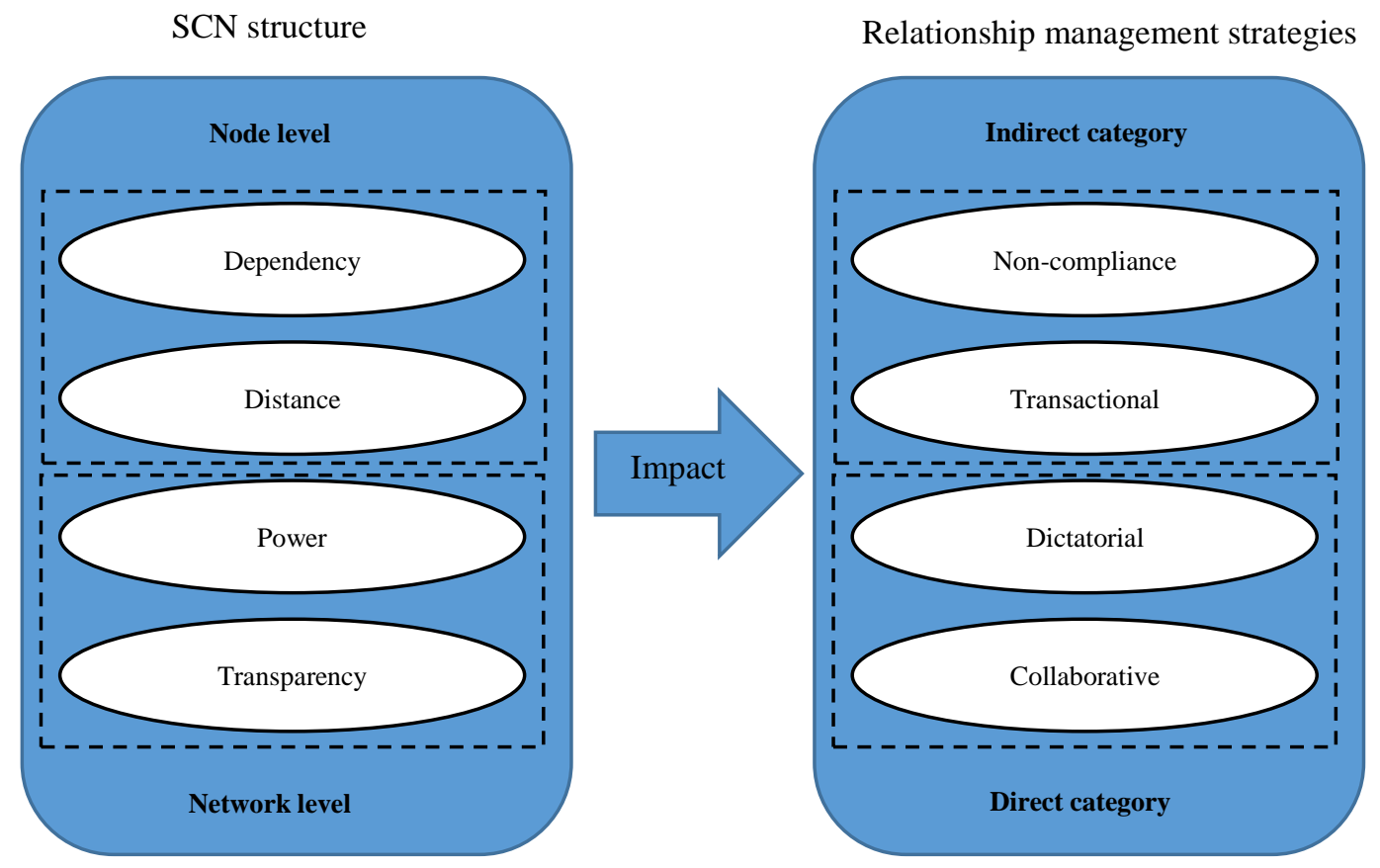

Figure 1. Conceptual framework

\section{Categorising various sustainability practices into relationship management strategies}

Based on a comprehensive review of the IMP, SSCM, SCN, and marketing literature, this paper evaluates how focal firms approach their SCN actors to manage sustainability issues, extends the work of Vurro, Russo and Perrini (2009) by emphasising the sustainability practices which large focal firms apply to their SCN, and categorises various sustainability practices in the literature into four distinct RMS, including 'non-compliance', 'transactional', 'dictatorial', and 'collaborative'.

\section{Non-compliance}

In a non-compliance RMS, the focal firms typically do not have the intention to make efforts to influence the SCN actors regarding sustainability issues. In other words, this type of RMS fails to address the demands for sustainability requirements from stakeholders, and the focal firms do not pay attention to the sustainability issues in their relationships with the SCN actors (Lee and Ball 2003; Meinlschmidt, Schleper and Foerstl 2018; Wilhelm et al. 2016b). The 
practices in this strategy may best apply to the less complex SCN or the firms that are not too visible by the end-user (Caridi et al. 2010; Parmigiani, Klassen and Russo 2011; Wilhelm et al. 2016b). The focal firms that are under less pressure from various institutions have the tendency to be followers and looking for the conservative approach such as implementing successful practices after they are validated by pioneer firms (Simpson, Power and Samson 2007). In addition, the focal firms in this strategy often have limited power when compared to other actors in the SCN (Esty and Winston 2009). They do not usually have sufficient financial or technical resources to urge their SCN actors to make them more sustainable (Delmas and Montiel 2009). Furthermore, this strategy may be useful when the information exchange with the SCN actors is more costly, ineffective, and uneconomical (Simpson, Power and Samson 2007; Vurro, Russo and Perrini 2009). However, ignoring sustainability issues in this type of relationship may have dire consequences such as losing support from influential NGOs (e.g. World Wide Fund and Rainforest Alliances) which has the potential to damage the focal firm's reputation (Kumar et al. 2017). In contrast, involving numerous SCN actors with sustainability practices can add more complexity to the SCN, which makes it more difficult for the focal firms to control these practices (Sarkis, Zhu and Lai 2011), therefore, potentially providing further benefits to focal firms (Kim et al. 2011).

\section{Transactional}

In a transactional RMS, the focal firms pay more attention towards pursuing sustainability issues. However, by adhering to the minimum standards and requirements compliant with regulations, the focal firms often seek only a minimum level of sustainability commitment (Lee and Ball 2003). In other words, by employing arm's-length interactions with the SCN actors, the focal firms seek short-term commitments and a low level of information sharing (Vurro, Russo and Perrini 2009). This may happen when the focal firms identify that these actors are not key players in their business environment or the focal firms have not sufficient power to influence those actors. For example, MacCarthy and Jayarathne (2012) indicated how successfully a supermarket retailer (a focal firm) used arm's length interactions (such as limited concern for monitoring the well-being of employees) to manage sustainability issues in their $\mathrm{SCN}$. In the case of environmental sustainability, environmental monitoring practices often concentrate on the outcomes of environmental initiatives (Paulraj and Blome 2017). For 
example, having certifications such as receiving ISO 14001 or EMAS, or being compatible with a specific legislation such as hazardous materials labeling and greenhouse gas emissions, or preparing the environment-related documentation (Vachon and Klassen 2006). To employ sustainability practices in the transactional strategy, the focal firms usually gather and process the SCN actors' information via publicly disclosed documentation or auditing by another actor (Min and Galle 2001; Meinlschmidt, Schleper and Foerstl 2018; Wilhelm et al. 2016b). For example, the focal firm can collaborate with NGOs to use their databases for monitoring its lower-tier suppliers (Miemczyk, Johnsen and Macquet 2012). The focal firms may ask their first-tier suppliers to improve the sustainability performance of their second-tier suppliers (Aßländer, Roloff and Nayır 2016). Wuyts and Van den Bulte (2012) name this approach "twostep" leverage in which focal firms call their first tier suppliers to influence on their second tier suppliers. Therefore, in this strategy, focal firms do not tend to put a high level of energy and time into the management of sustainability issues of their SCN actors.

\section{Dictatorial}

"A dictatorial solution is one in which the will of one individual always prevails" (Heal 1998, 8). The sustainability practices in this RMS often emerge when the focal firm has more power than its SCN actors, and because of its dominance, the focal firm can force the other actors to follow its edicts (Drucker and Noel 1986), and use their own resources to audit sustainability standards on a regular basis (Meinlschmidt, Schleper and Foerstl 2018). The auditing process may include various forms such as investigating waste, emissions, and working conditions (Bridges and Wilhelm 2008). The focal firms apply more proactive approaches as they become aware of the potential benefits that can be achieved from a commitment to sustainability (Lee and Ball 2003). In this strategy, the focal firms usually impose some norms, standards and practices (either created by themselves or that come from regulations) to manage sustainability issues throughout the SCN (Neville and Menguc 2006) and establish a set of procedures to implement them (Andersen and Skjoett-Larsen 2009). For example, Nike developed its own workforce and environmental standards to monitor the social and environmental issues of its suppliers (Awaysheh and Klassen 2010) or in another case, IKEA instituted its own corporate social responsibility (CSR) certificate to ensure that sustainability requirements were followed by its suppliers (Andersen and Skjoett-Larsen 2009). In other words, since the SCN actors 
cannot exert influence over the focal firms, the latter adopt the role of commander, setting the rules of sustainability issues for the SCN actors and urging them to follow the rules (Vurro, Russo and Perrini 2009). This condition can also create competition among SCN actors to follow the focal firms' instructions which in turn may impact on their future contracts with the focal firms (Wuyts and Van den Bulte 2012). For example, Sa Vinhas and Heide (2014) examine how different forms of competition among distributors and manufacturers can be beneficial to the buyers. By having the ability to make decisions independently through exerting economic and non-economic influences (Parmigiani, Klassen and Russo 2011), the focal firms can create pressure on their customers as well as suppliers (Maloni and Benton 2000). They can design incentive programs to encourage the desired behaviour and/or penalise non-compliance (Wathne and Heide 2004) (for a detailed overview, see Kishore et al. (2013). For example, as part of the supplier relationship management process, the focal firms can apply incentives (Andersen and Skjoett-Larsen 2009) or sanctions for supplier evaluation results (Peters 2010). In the most extreme case, the negative outcome can be accompanied by the termination of the business relationship (Delmas and Montiel 2009; Pullman et al. 2017; Ghosh and John 2009; Cui, Calantone and Griffith 2011), although, collaborating in sustainability practices rather than sanctions may result in the better sustainability performance (Aßländer, Roloff and Nayır 2016). Accordingly, this strategy is concerned with dictating instructions to the SCN actors to achieve desired outcomes.

\section{Collaborative}

The sustainability practices of a collaborative RMS are those that include both focal firms and others in the SCN directly implementing agreed upon approaches and are typically concerned with mutual sustainability outcomes for both involved parties. Collaboration is seen as a cornerstone to improving sustainability performance (Paulraj and Blome 2017; Soosay and Hyland 2015; Paulraj and Blome 2017), and can be considered a core theme of the marketing relationship (Chu, Chang and Huang 2011). Wathne and Heide (2004) found that collaborating with suppliers through supplier qualification programs can increase the ability of the focal firms to adopt uncertainty in their customer relationship management process. The focal firms develop the collaborative relationships with multi-stakeholders in terms of various joint rules (such as knowledge sharing) to make their SCN more sustainable (Vurro, Russo and Perrini 
2009; Watson et al. 2018). For example, seller investments and customer investments can play a key role in improving the strength of buyer-seller relationships (Boyle et al. 1992) between two firms (Zhang et al. 2016). These joint efforts and mutual investments can have considerable impact on ex-post transaction costs (Wathne et al. 2018). Zhang, Pawar and Bhardwaj (2017) argue that supplier development program such as collaboration and training can be positively effective in enhancing supply chain sustainability. In addition, by entering into a close partnership with the key SCN actors (both business and non-business actors), the focal firms can add more sustainability legitimacy to its reputation (Crespin-Mazet and Dontenwill 2012; Wilhelm et al. 2016b). For example, the focal firm may create a collaborative relationship with a lower tier supplier through providing training on how to adopt cleaner production methods and, at the same time, work closely with an non-governmental environmental organisations (NGO) to generate a specific environmental standard (Tachizawa and Wong 2014; Wilhelm et al. 2016b). In another example, cross-national collaboration of multinational companies can be significantly effective in building new product advantage (Griffith and Lee 2016), which can be considered as a main part of the sustainable product life cycle. Crespin-Mazet and Dontenwill (2012) conducted a case study and explained how the focal firm signed an agreement to buy materials at a certain volume and price from its suppliers to encourage cultivating plants in compressed clods. The focal firm can also develop a partnering relationship with non-business actors such as militant organisations to create a corporate legitimacy (Crespin-Mazet and Dontenwill 2012). Therefore, focal firms that apply this strategy spend many resources to manage sustainability in their SCN.

\section{Potential for a hybrid approach}

The focal firms may also use one or more of the four RMS to improve sustainability in their SCN simultaneously. For example, a focal firm may: (1) keep the existing relationship, regardless of sustainability improvement within it (non-compliance), (2) seek for minimum requirement of social and environmental standards in lower-tier suppliers with the help of third parties (transactional), (3) force suppliers to implement environmental management systems (dictatorial), (4) extend the business volume with some existing suppliers who already meeting sustainability requirements (dictatorial, collaborative), and (5) develop close partnerships with NGOs, activists and militant organisations (collaborative). This means that the focal firms may 
develop and maintain different types of relationships (through various sustainability practices) with both upstream and downstream actors that form their own network environment to achieve competitive advantage (Chang, Chiang and Pai 2012; Meinlschmidt, Schleper and Foerstl 2018).

\section{Factors to conceptualise the supply chain network structure}

The analysis of the SCM context in which sustainability practices are implemented from the network perspective can determine which RMS are most effective to implement sustainability practices (Tachizawa and Wong 2014). Studies on the sustainable development concept that incorporate the network perspective into the SCM, such as that of Frostenson and Prenkert (2015), highlight the fact that firms need to understand the embeddedness of SCN actors since it can limit individual firms' actions to manage sustainability issues (Miemczyk, Johnsen and Macquet 2012). Thus, the structure or pattern of interactions among the firms and its SCN actors can influence the behaviour of the firms regarding managing sustainability issues within the network (Roscoe, Cousins and Lamming 2016; Pullman et al. 2017). This means focal firms need to analyse the structure of the $\mathrm{SCN}$ to find an appropriate set of sustainability practices through effective RMS.

The pattern of interactions in the network can be analysed at two levels. The first level, which is called node level (Bellamy and Basole 2013), is about how a firm is in control of other SCN actors (such as the focal firm) and is concerned with the management of interactions between two SCN actors (Ritter, Wilkinson and Johnston 2004). This is similar to the network centrality in the social network context in which a firm's access to other actors in the SCN can be measured (Srinivasan, Wuyts and Mallapragada 2018; Van den Bulte and Wuyts 2007). The second level, which is called the network level (Bellamy and Basole 2013), is about how a firm can influence and be influenced regarding the function of the whole network (Ritter, Wilkinson and Johnston 2004). "The extent to which actors in the SCN are connected to each other and their relative position matter in shaping reciprocal influences and acceptance within the network" (Vurro, Russo and Perrini 2009, 612). For example, a focal firm with low power over a SCN actor may result in a lack of influence over its practices (node level), and a SCN actor's

poor interconnectedness within the network can impede the transmission of stakeholder pressure on its performance (network level) (Gualandris and Pagell 2015). Thus, how much a 
focal firm can address sustainability issues within a specific SCN actor depends largely on the level of influence it has on the other SCN actors and also the level of information that other SCN actors (stakeholders) can access regarding this SCN actor (Parmigiani, Klassen and Russo 2011).

Due to the importance of the level of influence and level of information availability in developing strategic actions of managing sustainability issues to successfully respond to competition within the SCN (Chang, Chiang and Pai 2012; Parmigiani, Klassen and Russo 2011; Vurro, Russo and Perrini 2009), this paper extends the work of Awaysheh and Klassen (2010) by analysing the supply chain structure from the network perspective, and suggests there are four factors which can affect the type of RMS to improve sustainability of the SCN. These factors can be used to conceptualise the pattern of interactions in the SCN structure, and consequently have significant impacts on the RMS chosen by the focal firms in the sustainability context: dependency, distance, power, and transparency. This paper applies these four factors, by examining two levels of influence and information availability from both the node and network level.

The level of influence in a dyadic relationship can be characterised by the dependency which comes from a power imbalance (asymmetrical interdependence) that happens if one firm is more dependent than the other firm (Touboulic, Chicksand and Walker 2014; Gundlach and Cadotte 1994). Therefore, at the node level, "power is deeply rooted in interdependence, so the more dependent one actor is on another, the more power the latter has over the former" (EgelsZandén, Hulthén and Wulff 2015, 101). This means in the two firm relationships, dependency can be considered the obverse of power (Emerson 1962). However, power is not limited to a dyadic relationship in which two actors interact but also resides within the network in which the firm is embedded and can affect the firm's strategies and behaviour (Meqdadi, Johnsen and Johnsen 2016). Therefore, the level of influence at the network level can be characterised by the power which can come from a variety of resources such as having a high market share or highly differential technology (Chang, Chiang and Pai 2012).

The level of information availability at the node level can be characterised by the distance between two actors. Indeed, the access to effective information and knowledge from various 
SCN actors can be eased for focal firms by the length of the path between them (Bellamy, Ghosh and Hora 2014). The level of information availability at the network level can be characterised by the firm's transparency which can take the form of, for example, sustainability reports, environmental product declarations, and sustainability certifications (Egels-Zandén, Hulthén and Wulff 2015). The transparency reflects the degree that the information is available in appropriate quantity and quality for all the firm's stakeholders (SCN actors) (Wognum et al. 2011), and can be considered as a "foundational tool" for addressing stakeholder pressure and improving responsible management practices (Parris et al. 2016, 223). Thus, to survive in the competitive marketplace, firms need to respond to stakeholder pressure by information processing and increased transparency to positively improve the firms' reputation (Wognum et al. 2011; Gouda and Saranga 2018).

Those factors are categorised in two levels. At the node level, the level of influences can be identified by how much a SCN actor is dependent on the focal firm, and the level of information availability can be identified by how much distance exists between the focal firm and a SCN actor. At the network level, the level of influences can be identified by how much a SCN actor is considered powerful in the network, and the level of information availability can be identified by how much a SCN actor is transparent.

\section{Dependency}

In the SCN, dependency is concerned with the extent to which a firm relies on the other actors of the SCN for their resources and capabilities (Awaysheh and Klassen 2010; Frazier 1983a, b; Frazier, Gill and Kale 1989). This means the firm's power within the reciprocal relationships is driven by its dependence on other firms (Frazier, 1983a; Frazier et al. 2009). For example, a dealer's dependence on its manufacturer can be based on the sales volume contributed by the manufacturer (Frazier, Gill and Kale 1989). Dependency theory (Pfeffer and Salancik 1978) suggests that as the number of potential suppliers for a firm reduces, the firm's influences decrease. This factor can have a significant impact on the focal firm's behaviour (Jorge and Jerónimo 2017; Salonen and Gabrielsson 2012; Meinlschmidt, Schleper and Foerstl 2018; Wilhelm et al. 2016b), and can be best understood through the social relationships context (Narasimhan et al. 2009). Ritter, Wilkinson and Johnston (2004) presented a model which categorises four types of relationships between two firms in the network based on how they are 
dependent on each other. For example, inequity in a buyer-supplier relationship can significantly affect the extent of resources that the supplier shares with its buyer (Griffith et al. 2017). The focal firm has a limited ability to influence and control changes in the operations of its suppliers if the focal firm is highly dependent on its suppliers (Awaysheh and Klassen 2010). Indeed, signalling by the focal firm is less likely to motivate the suppliers' actions regarding the specific objectives if the focal firm is dependent on the supplier (Dixit and Nalebuff 1993). In particular, focal firms may follow sustainable development objectives to find legitimate suppliers and reduce their dependence to the suppliers which have sustainability incursions (Connelly, Ketchen and Slater 2011).

The role of the dependency in the SCM context has gained considerable attention among researchers (Griffith et al. 2017; Hoejmose, Grosvold and Millington 2013; Steinle, Schiele and Ernst 2014), particularly in the application of the SSCM practices (Meinlschmidt, Schleper and Foerstl 2018; Tachizawa and Wong 2014; Wilhelm et al. 2016b). For example, Awaysheh and Klassen (2010) argued that as the dependency on the customers increases, the focal firms have more tendency to apply socially responsible practices. This is mainly because the extent of the influence that customers can exert on the focal firm to follow sustainability practices (Delmas and Montiel 2009). However, they could not find enough evidence to find such a relationship when the focal firms were dependent on their suppliers. In a comprehensive literature review, Tachizawa and Wong (2014) identified dependency as being the main variable which can affect the approaches chosen by the focal firm to manage sustainability issues in their SCN. Similarly, in the marketing research studies, dependency has been recognised as a focal factor which can affect firms' strategy, behaviour and economic outcomes (e.g., Frazier 1983a, b; Frazier et al. 1989; Frazier and Rody 1991; Heide and John 1988; Hibbard et al. 2001; Kumar et al. 1995; Lusch and Brown 1996; Scheer, Miao and Palmatier. 2015). For example, dependency on suppliers can affect the level of governance mechanisms which is elected by focal firms (Gilliland, Bello and Gundlach 2010), and also increase focal firm's loyalty to the suppliers (Scheer, Miao and Garrett 2010). Scheer, Miao and Palmatier. (2015) found that dependency has substantial effects on the quality of relationship and cooperation. This leads to the significant role of dependency in the focal firms' RMS. As previously discussed, focal firms apply four types of RMS (non-compliance, transactional, 
dictatorial, and collaborative) to manage sustainability issues within their SCN. Therefore, this paper argues that dependency can affect each RMS. The effects can be captured in the following propositions:

Pla: Dependency can affect the focal firms' use of non-compliance RMS to manage sustainability issues in the SCN.

P1b: Dependency can affect the focal firms' use of transactional RMS to manage sustainability issues in the SCN.

Plc: Dependency can affect the focal firms' use of dictatorial RMS to manage sustainability issues in the SCN.

P1d: Dependency can affect the focal firms' use of collaborative RMS to manage sustainability issues in the SCN.

\section{Distance}

As distance increases, focal firms have some difficulties related to data gathering, evaluation, and implementation (Klassen and Vachon 2003), which can affect the focal firms' incurred cost (Liu, Bui and Leach 2013). Closeness can be referred to as the intensity of interaction between a focal firm and its SCN actors such as suppliers which can vary from an arm's-length relationship to close collaboration (Wuyts and Geyskens 2005). Three sub-factors can conceptualise the distance in the SCN, including geographical distance which is related to the physical distance between the actors in the SCN (Griffith and Dimitrova 2014; Watson et al. 2018), cultural distance which refers to the cultural differences that exist between the societies in which the firms are located (Grewal et al. 2018; Tihanyi, Griffith and Russell 2005), and organisational distance which is concerned with the number of tiers that exists among the various actors in the SCN (Awaysheh and Klassen 2010; Parmigiani, Klassen and Russo 2011; Roth et al. 2008). As the distance between the actors in the SCN increases, focal firms make more effort in coordination activities (Mares 2010; Simpson, Power and Samson 2007; Bellamy, Ghosh and Hora 2014; Carter, Rogers and Choi 2015). This may happen due to the numerous difficulties in establishing trust and developing rich exchanges of information as a result of too much distance, making it more complex to create an environment for coordination 
and collaboration (Parmigiani, Klassen and Russo 2011).. For example, two manufacturing plants which are located in two different countries may share a similar standard of workplace conditions as they are both owned by a parent firm (small cultural differences) or in another case, they may be located in the same area but each of them is owned by focal firms from two different countries (large cultural differences). Griffith and Dimitrova (2014) found that effective interfirm communication is essential to reach the maximum benefits of strong relational networks. Distance can also be considered as a significant factor in determining the nature of an international interfirm marketing collaboration (Dahlquist and Griffith 2015). Therefore, the effect of this factor on SSCM needs to be analysed (Dubey, Gunasekaran and Papadopoulos 2017; Meinlschmidt, Schleper and Foerstl 2018; Wilhelm et al. 2016b).

Similarly, a multi-industry survey among Canadian focal firms shows a positive relationship between the length of SC and the adoption of socially responsible practices. Indeed, as the number of tiers increases, complexity and uncertainty increases, and focal firms adopt more complex monitoring systems (such as auditing social issues based on the standards) to manage sustainability issues (Awaysheh and Klassen 2010). In addition, Hoejmose, Grosvold and Millington (2013) argued that both joint dependency and buyer power become increasingly significant determinants of socially responsible practices as geographical distance increases. This means distance can be a significant factor which can affect the types of relationships the focal firms can choose in their SCN (Tachizawa and Wong 2014). Therefore, considering the arguments offered previously on four types of RMS that focal firms apply to manage sustainability issues within their SCN, the following proportions are suggested:

P2a: Distance can affect the focal firms' use of non-compliance RMS to manage sustainability issues in the SCN.

P2b: Distance can affect the focal firms' use of transactional RMS to manage sustainability issues in the SCN.

P2c: Distance can affect the focal firms' use of dictatorial RMS to manage sustainability issues in the SCN. 
P2d: Distance can affect the focal firms' use of collaborative RMS to manage sustainability issues in the SCN.

Power

In the SCN, power is a firms' ability to influence and control other actors (Pilbeam, Alvarez and Wilson 2012; Frazier and Antia 1995), and can provide efficent outcomes in the bargaining process (Dwyer and Walker 1981). However, imbalanced power may result in creating asymmetrical outcomes such as reducing the SCN actors' satisfaction with the relationships (Reve and Stern 1979). Power can come from various resources, such as having a high market share, high growth demand, highly distinctive technology, critical components and products, high prestige and reputation, and being in a high concentrated and consolidated part of the industry structure (Chang, Chiang and Pai 2012). These aspects can affect the relationship success of the actors in the supply chain (Bandara et al. 2017), and have been considered a great area of interest for business-to-business marketing researchers (Johnsen and Lacoste 2016). Huxham and Beech (2008) consider resources and legitimacy as being the two main sources of power for focal firms. For example, possessing access to rare resources can provide more power for the focal firms in their SCN (Alvarez, Pilbeam and Wilding 2010). In addition, developing various relationships with the $\mathrm{SCN}$ actors, which are legitimate (for example, in the case of sustainability), gives the focal firms more power to influence the other SCN actors to follow up their own policies (Crespin-Mazet and Dontenwill 2012). Having valuable resources and the position of the focal firm in the SCN (customers' customer, customer, supplier, suppliers' supplier) can be considered as two sources of the power (Mena, Humphries and Choi 2013). Similarly, a firm's structural position within its SCN can affect the firm's power and influence over the other actors within the SCN (Kim et al. 2011). In comparison to dependency, power is not limited to a dyadic relationship in which two actors interact but also resides within the network in which the firm is embedded and can affect the firm's strategies and behaviour (Chang, Chiang and Pai 2012; Meqdadi, Johnsen and Johnsen 2016).

Within the SCN, power plays a critical role in the adoption of sustainability practices (Meinlschmidt, Schleper and Foerstl 2018; Tachizawa and Wong 2014; Wilhelm et al. 2016b) and particularly can affect the depth of the collaboration between the focal firms and the other SCN actors (Kähkönen 2014). For example, a powerful focal firm can urge the necessary 
sustainability standards are met by suppliers (Ciliberti et al. 2009), and in contrast, the lack of sufficient power over the suppliers can limit the enforcement of sustainability practices in the SCM (Hoejmose, Grosvold and Millington 2013). This means when a focal firm seeks to coerce a supplier (to comply with their required instruction) without providing sufficient direct or indirect rewards, the supplier may not perceive this compliance worthwhile and may select to terminate the relationship (Dwyer, Schurr and Oh 1987). This means considering power as being a significant factor can help focal firms to decide which types of relationships can be effective under specific circumstances (Narasimhan et al. 2009; Tachizawa and Wong 2014). Regarding the previous arguments of four types of RMS that focal firms apply in the sustainability context, the following propositions are suggested:

P3a: Power can affect the focal firms' use of non-compliance RMS to manage sustainability issues in the SCN.

P3b: Power can affect the focal firms' use of transactional RMS to manage sustainability issues in the SCN.

P3c: Power can affect the focal firms' use of dictatorial RMS to manage sustainability issues in the SCN.

P3d: Power can affect the focal firms' use of collaborative RMS to manage sustainability issues in the SCN.

\section{Transparency}

Transparency refers to the degree to which information is readily available to the public, the end-consumers, and the other actors within the SCN (Awaysheh and Klassen 2010). For example, as the institutional pressure becomes more intense, focal firms become more visible to the media (Simpson, Power and Klassen 2012). In this regard, focal firms typically show more intention towards the proactive approach to adopt the sustainability practices in their SCN (Esty and Winston 2009; Meinlschmidt, Schleper and Foerstl 2018; Wilhelm et al. 2016b). Large firms with visible brand names may pay more attention to protecting themselves against the criticism of social issues in their SCN (Awaysheh and Klassen 2010). Therefore, the extent to which the SCN actors are transparent or subjected to various stakeholders such as the public, 
the media, and NGOs can influence the degree to which a focal firm proactively applies the sustainability practices, for example, related to social issues (Awaysheh and Klassen 2010).

Similarly, Parmigiani, Klassen and Russo $(2011,215)$ used accountability to refer to the concept of transparency and define it "as the extent to which firms are required or expected to justify their decisions and actions for product design, sourcing, production or distribution to stakeholders". They argue that this factor is a pivotal construct for focal firms to help them in deciding which types of approaches they need to choose to manage the sustainability issues in their SCN (the higher accountability, the higher motivation towards a proactive approach to the management of sustainability issues) (Parmigiani, Klassen and Russo 2011). This means transparency can be recognised as a key factor which has a significant effect on the focal firms' RMS (Awaysheh and Klassen 2010; Tachizawa and Wong 2014). Considering the four types of RMS that focal firms apply to manage sustainability issues within their SCN, the following propositions are sugested:

P4a: Transparency can affect the focal firms' use of non-compliance RMS to manage sustainability issues in the SCN.

P4b: Transparency can affect the focal firms' use of transactional RMS to manage sustainability issues in the SCN.

P4c: Transparency can affect the focal firms' use of dictatorial RMS to manage sustainability issues in the SCN.

P4d: Transparency can affect the focal firms' use of collaborative RMS to manage sustainability issues in the SCN.

Table 1 provides the connections among the major constructs in this paper and highlights the authors who have investigated the respective connections. 
Table 1. Researchers who have investigated the connection among the conceptual framework's constructs

\begin{tabular}{|c|c|c|}
\hline SCN structure & RMS & References \\
\hline \multirow[t]{4}{*}{ Dependency } & Non-compliance & (Wilhelm et al. 2016b) \\
\hline & Transactional & (Awaysheh and Klassen 2010; Jorge and Jerónimo 2017) \\
\hline & Dictatorial & (Connelly, Ketchen and Slater 2011) \\
\hline & Collaborative & (Jorge and Jerónimo 2017; Awaysheh and Klassen 2010) \\
\hline \multirow[t]{4}{*}{ Distance } & Non-compliance & - \\
\hline & Transactional & (Awaysheh and Klassen 2010; Klassen and Vachon 2003) \\
\hline & Dictatorial & \\
\hline & Collaborative & $\begin{array}{l}\text { (Awaysheh and Klassen 2010; Klassen and Vachon 2003; } \\
\text { Hoejmose, Grosvold and Millington 2013; Parmigiani, } \\
\text { Klassen and Russo 2011) }\end{array}$ \\
\hline \multirow[t]{4}{*}{ Power } & Non-compliance & - \\
\hline & Transactional & (MacCarthy and Jayarathne 2012) \\
\hline & Dictatorial & $\begin{array}{l}\text { (Andersen and Skjoett-Larsen 2009; Ciliberti et al. 2009; } \\
\text { Hoejmose, Grosvold and Millington 2013; Neville and } \\
\text { Menguc 2006; Peters 2010) }\end{array}$ \\
\hline & Collaborative & $\begin{array}{l}\text { (MacCarthy and Jayarathne 2012; Parmigiani, Klassen and } \\
\text { Russo 2011) }\end{array}$ \\
\hline \multirow[t]{4}{*}{ Transparency } & Non-compliance & (Parmigiani, Klassen and Russo 2011) \\
\hline & Transactional & $\begin{array}{l}\text { (Awaysheh and Klassen 2010; Parmigiani, Klassen and Russo } \\
\text { 2011; Wilhelm et al. 2016b) }\end{array}$ \\
\hline & Dictatorial & (Parmigiani, Klassen and Russo 2011) \\
\hline & Collaborative & $\begin{array}{l}\text { (Awaysheh and Klassen 2010; Grimm, Hofstetter and Sarkis } \\
\text { 2016; Wilhelm et al. 2016b) }\end{array}$ \\
\hline
\end{tabular}

\section{Discussion}

There are also other factors that determine the pattern of interactions in the SCN structure that can affect the type of approach that firms apply to manage sustainability issues in the SCN. For example, Tachizawa and Wong (2014) identified seven factors that can affect the type of sustainability practices that a firm employs in the SCN. However, aside from power, stakeholder pressure, dependency, and distance, the other three factors (material criticality, industry, and knowledge resources) are not directly related to the pattern of interaction in the SCN structure, and indeed, are partly covered by other four factors. For example, being in a more static or dynamic industry context can be mediated by stakeholder pressure (Betts, Wiengarten and Tadisina 2015), and material criticality in the form of resource scarcity (Touboulic, Chicksand and Walker 2014). Knowledge resource in the form of expertise and skills can also be considered as one of the power sources (Schneider and Wallenburg 2012). Awaysheh and Klassen (2010) applied three factors (transparency, dependency, and distance) 
to characterise the structure of the SC to identify the impact of the structure on the use of supplier socially responsible. However, in their study, they did not explain the extent to which how much the actors in the SC context are considered to be powerful from the perception of other SC actors, which can affect the form of relationship chosen by the focal firm (Kähkönen 2014). Caridi et al. (2010) suggested virtuality and complexity as being two main features of the SCN configuration. However, the virtuality, which can be measured by "the amount of supply chain activities that are external to the focal firm" (Caridi et al. 2010, 376) can be covered by dependency (Hoejmose, Grosvold and Millington 2013). The complexity which can be measured by "the number of connections among the nodes" (Caridi et al. 2010, 376), can be covered by the power (Kim et al. 2011). Bellamy, Ghosh and Hora (2014) found two important structural characteristics of the SCN (accessibility and interconnectedness) that may affect the flow of information and knowledge between SCN actors. The SCN accessibility, which can be defined as "how effectively a firm is able to access the different sources of information and knowledge assets in the network", can be covered by the distance (Bellamy, Ghosh and Hora 2014, 359). The SCN interconnectedness which can be defined as "how these sources of information and knowledge are structurally inter-linked together in the network" (Bellamy, Ghosh and Hora 2014, 359), can be covered by the transparency of the SCN (Turcu, Graur and Turcu 2009).

As seen in Figure 1, to improve sustainability in the $\mathrm{SCN}$, the focal firm must choose one or more RMS which consequently provide the main framework to select the specific types of sustainability practices. These RMS are divided into two categories. The indirect category which includes non-compliance and transactional RMS are applied when the focal firm uses another resource (such as third parties, NGOs) to manage sustainability issues in its SCN actors. In contrast, in the direct category which includes dictatorial and collaborative RMS, the focal firm uses its own resources and directly involves in the process of managing sustainability issues in its SCN actors. In this process, the focal firm must consider the impact of the SCN structure on the RMS, as the various pattern of interactions among the actors in the SCN can provide different conditions for the focal firm to choose RMS. This implies that based on the combination of analysis at the node level (which can be examined by dependency and distance) and at the network level (which can be examined by power and transparency) for each actor in 
the SCN structure, the focal firm can identify which types of RMS are effective for the SCN actor to implement sustainability practices. For example, to make the SCN more sustainable, a retailer may begin with the analysis of the pattern of interactions among the various actors in the SCN. By interpreting each SCN actor's position (based on how much the actor is dependent on the retailer, has distance to the retailer, has the power, and is transparent to the whole network), the retailer can identify which actor has to be chosen for, for example, more fierce approach. Accordingly, the retailer may add some standards of workplace conditions in their supplier relationship management process to force those small suppliers to follow up such as sustainability practice. The same analysis needs to be conducted when the retailer wants to collaborate with the key suppliers to jointly run mutual projects, such as a NPD process, marketing, or manufacturing activities that use recyclable materials. In this regard, the focal firm can save time and money by assigning the appropriate type of sustainability practices through an effective RMS to each SCN actor to manage the sustainability issues across the SCN.

\section{Conclusion and implications}

This paper addresses gaps in the IMP, SSCM, SCN, and marketing literature by providing a novel conceptual framework, based on the network-based approach, in the SSCM context to help focal firms determine the appropriate type of industrial marketing relationships to achieve their sustainable development objectives. In addition, studies that analyse SSCM from the network perspective highlight that a focal firm needs to recognise its embeddedness within the wider stakeholder network (Miemczyk, Johnsen and Macquet 2012). This implies the significant influences of the structure or pattern of interactions between the focal firm and its SCN actors on the way the focal firm treats each actor in the network to manage sustainability issues (Roscoe, Cousins and Lamming 2016), which have been neglected in the SSCM literature (Meinlschmidt, Schleper and Foerstl 2018). In doing so, this paper advances the understanding of a SCN structure in the literature by analysing how the construction of interactions among the SCN actors can affect the focal firm's decisions to find effective RMS which can lead to the appropriate types of sustainability practices.

This paper has shown how focal firms can incorporate sustainable development objectives into their SCN. By examining the IMP, SSCM, SCN, and marketing literature, the importance of 
having a network perspective in the SSCM context and creating the effective RMS to access to the valuable resources required for the sustainable development objectives has been highlighted. Accordingly, various types of sustainability practices, have been reviewed and based on the way focal firms treat their SCN actors when managing sustainability issues, they are categorised into one of the four distinct RMS (non-compliance, transactional, dictatorial, and collaborative). Then, to explain how the focal firms can identify which types of RMS are effective to implement specific types of sustainability practices, this paper emphasised the role of the SCN structure which consists of the pattern of interrelated actors in the focal firms' SCN.

To analyse the SCN structure more precisely, four sub-factors were identified (transparency, dependency, distance, and power) which may help focal firms to conceptualise the SCN structure. Finally, in the last section, a conceptual framework was provided to help focal firms in the process of incorporating sustainable development objectives into their SCN. By presenting the conceptual framework, this paper argues that to make the SCN more sustainable, the focal firms need to develop and maintain different types of RMS (set of sustainability practices). More importantly, the conceptual framework highlights that the focal firms need to consider the impact of the SCN structure on the RMS to make improvement in the sustainable development objectives in their SCN. This means that the focal firm can use the model to decide on the specific structure in its SCN, and which appropriate types of sustainability practices have to be employed in which business processes. Accordingly, 16 propositions are outlined, which explain the effect of SCN structure on the types of RMS required to incorporate the sustainable development objectives into focal firms' SCN and recommend that researchers test the propositions using an empirical data for validation.

\section{Limitations and future research}

The main limitation of this paper relates to the propositions, which were developed from the existing literature, therefore, conducting empirical studies such as an in-depth case study, and a survey on a large scale can help validate the propositions. Another limitation is concerned with the position of the focal firms in their SCN, which can affect the ability of the focal firms to diffuse sustainability practices throughout their SCN (Tachizawa and Wong 2014). This paper mainly explores the large firms' different use of sustainability practices and how they 
interact with their different SCN actors. However, the impact of the patterns of interactions (among various SCN actors) on the focal firms' position has not been addressed. Since analysing network of interconnected firms can be effective in the diffusion of sustainability practices (Connelly, Ketchen and Slater 2011), using theories such as social network theory (Wuyts and Van den Bulte 2012; Tracey, Heide and Bell 2014) and methods such as social network analysis (Chang, Chiang and Pai 2012; Wichmann and Kaufmann 2016) could provide a foundation for future research. This allows researchers to analyse the central position of the focal firms in their SCN, the distribution of the power among SCN actors, and potentially support this paper's conceptual framework by providing metrics that could be quantified, analysed and visualised. Combining this paper's conceptual framework with other existent framework such as governance value analysis (GVA) proposed by Ghosh and John (2012) can be other valuable venue for future research to consider sustainability in the RMS. This paper did not consider the effect of time duration on the RMS. Since relationships can be changed over their life cycle (Dwyer, Schurr and Oh 1987; Griffith et al. 2017), examining this conceptual framework via longitudinal methodology design can be a suitable area for future research.

\section{Disclosure statement}

No conflict of interest was reported by the authors.

\section{Implications for business marketing practice}

Although this paper is conceptual and the are no empirical results, industry professionals can benefit from the conceptual framework and propositions outlined in this paper. According to Wolf (2014), firms are in need of a structured framework to help achieve sustainable development objectives. This is also important as incorporating sustainability principles into different business practices have entered the education context (for example see Bridges and Wilhelm 2008). In this regard, the development of this paper's conceptual framework and application to the focal firm's SCN, provides useful considerations for both marketing managers and supply chain managers. Firstly, by analysing the position of various types of actors (such as customers, manufacturers, suppliers, NGO) in the SCN via the four identified factors related to the SCN structure (dependency, distance, power, transparency), these 
managers can identify the key network actors that can have a considerable impact on the sustainability of the SCN. Each SCN actor may for example, have different impacts on the sustainability performance of the focal firms such as how powerful suppliers can affect the sustainability of the SCN as they have more influence on the relationships with other actors in the SCN. By identifying these powerful suppliers in the network, managers can facilitate the process of improving sustainability by promoting appropriate types of relationships such as partnerships and joint initiatives related to sustainable development objectives. Having mutual sustainability-related projects in different contexts can be beneficial for both sides (focal firm and its SCN actor), as seen for example, how marketing managers can benefit from collaborating with powerful suppliers to make sustainable NPD decisions. As developing new products are costly and need a substantial investment of time and resources, focal firms can support the required investment (for example in critical technologies (Melander, Rosell and Lakemond 2014)) with the help of their powerful suppliers, which result in a durable presence in the market. In addition, working closely with suppliers can assist focal firms to prevent the excessive levels of product capibility which have been provided by suppliers (Lukas, Whitwell and Heide 2013). This form of relationship can influence the effectiveness of NPD projects leading to the greater return on investment over the long term (Tracey, Heide and Bell 2014).

Secondly, it may be prudent for the focal firms to identify "lower-tier" actors because moving towards sustainable development objectives increasingly shifts to managing sustainability issues beyond the focal firms (Meinlschmidt, Schleper and Foerstl 2018). Some SCN actor's non-compliance with sustainability standards however, may create a negative public image for customers who can hold the focal firms accountable for such a misbehaviour. Of interest is that frequently, these non-sustainable actions are conducted at the sub-actor level (Wilhelm et al. 2016b). At first glance, these actors may seem peripheral in the SCN, but by examining them deeply via the four identified factors related to the SCN structure, some of these actors may become a key player. For example, some suppliers may have numerous links (information flow and material flow) with key actors (such as competitors, NGOs) in the SCN. These suppliers may be quite remote from focal firms or may not very dependent on them, however, they may be powerful actors. Two examples of this are where supplier have a relationship with competitors or may be too transparent due to having a relationship with prominent NGOs in 
the SCN. These supplier characteristics (being powerful and transparent) can be a potential opportunity for focal firms to employ a specific RMS to exert some control over them in managing sustainability issues. By identifying these actors, marketing managers can identify new developments in the industry in terms of sustainability issues undertaken by other focal firms (competitors) in the SCN whilst protecting their firms from negative publicity created by inappropriate behaviours. In other words, some actors neglected by focal firms may emerge as becoming important since they are critical for other key actors in the SCN. These actors could be the main target for the focal firm to establish a quality relationship that enables the management of sustainability issues. In this way, they can create a balance between the cost their firms incurred (for example environmental cost (Kotler 2011)) and their growth goals to follow sustainability.

Thirdly, the relationship management literature has largely concentrated on long-term relationships, highlighting the necessary requirements on how to achieve a long-term exchange (Mysen, Svensson and Högevold 2012). In addition, the governance design principles and value analysis can affect price determination process (John 2017) and types of contracts used between two firms (Ghosh and John 2005). However, in the sustainability context, the focal firm may not apply sustainability practices to each individual actor by having a close relationship within the $\mathrm{SCN}$ because of the costs associated with the practices and it being nearly impossible to manage thousands of low-tier actors in relation to sustainability issues (Rauer and Kaufmann 2015; Meinlschmidt, Schleper and Foerstl 2018). The high upfront cost of sustainability practices can also be considered an important barrier to implementing SSCM (Walker, Sisto and McBain, 2008). Using the conceptual framework in this paper can encourage further discussion and assist managers in reducing the cost barrier by allocating the right practices for the right actors through adoption of an effective RMS. Each RMS can have a stake of claiming expected share of value generated by involved SCN actors, which can be managed by assigning specific investment in the effective RMS (Ghosh and John 2005). By analysing each actors' position in relation to each of the four identified factors within the SCN structure, focal firms can implement such practices in a cost-effective manner. For example, the focal firm may focus on reinforcing a relationship with the legitimate actors such as an NGO (e.g. Greenpeace) through collaborative projects, thus offering natural solutions which 
may have considerable costs. These type of marketing costs can be justified as being connected with legitimate actors can provide more sustainable legitimacy for focal firms (Crespin-Mazet $\&$ Dontenwill 2012). This is also helpful for multinational companies, which are dealing with the increased complexity of allocating adequate investment to manage their global sourcing and marketing activities (Pagano 2008). For multinational companies, appropriate assigning of marketing resources to foreign partners and stakeholders can be a vital component in their strong presence in the market (Grewal et al. 2018) as it can provide better information and knowledge creation process Watson et al. 2018). In this way, the focal firms can leverage stakeholder pressures in terms of sustainable supply chain activities effectively.

Fourthly, focal firms can change the structure of the SCN in favour of applying a specific RMS to a SCN actor. The different structure may require different strategies by focal firms to cope with sustainability issues in the SCN (Tachizawa and Wong 2014). Building a close relationship however, is not always the best RMS as, for example, some focal firms may not need or want to establish a close relationship with all of their suppliers (Daugherty 2011). This paper's conceptual framework provides four RMS, which focal firms can apply according to their SCN structure. The transition between different RMS can be possible as the focal firms have the ability to remodel the SCN structure or the pattern of interactions with their SCN actors. For example, by identifying more alternative suppliers (that have reputations in the following sustainability standards) for bottleneck products (Kraljic 1983), the focal firms can have more leeway to choose a different RMS. By doing this, the focal firms can change the dependency factor in the SCN structure. This means adding new (legitimate) suppliers to the supply base decreases the focal firm's dependency on the previous suppliers which results in reducing the complexity of the supply. In this new situation, the focal firm may use a different RMS that needs less time and effort than a traditional one to follow sustainability issues with the previous suppliers (which may have no intention of adopting sustainability standards) and instead building a closer relationship with the new (legitimate) suppliers. Thus, the focal firms can employ their desired RMS based on changing the pattern of interactions in the SCN structure via focusing on the four identified factors.

Fifthly, similar to the focal firms, SCN actors can also analyse their overall network position in the SCN and shape it based on their strategic actions. The different types of relationships 
that a SCN actor maintains with other SCN actors (particularly with focal firms) will, in turn, influence the degree of involvement and how they interact and negotiate over time (Håkansson \& Ford 2002). This may also affect the SCN actors' interfirm partnerships over time (Cui, Calantone and Griffith 2011). However, an existing SCN structure can be considered as the main constraint for SCN actors in aligning with their focal firms' intentions towards more collaboration (Gualandris and Pagell 2015). In this way, the SCN actors can overcome this constraint by analysing the shape of SCN structure with four identified factors. For example, they can change the configuration of the interactions to receive more attention from their focal firms, promoting products' speed to market (Tracey, Heide and Bell 2014). Marketing managers can work on the SCN structure by decreasing the distance with their key customers (focal firms) to facilitate the information exchange that can result in better communication. Through implementing business to business infrastructure such as electronic data interchange (EDI), they can provide a better base for establishing a close relationship with their key customers. As a result, the SCN actors can benefit from the extensive knowledge, joint learning and the provision of technical assistance by the focal firms regarding the sustainability issues and improve themselves in this area, which may result in a new source of income from a sustainability context. In doing so, the conceptual framework within this paper, provides managers with guidelines to help them make informed strategic decisions regarding the effective diffusion of sustainability practices throughout their $\mathrm{SCN}$ and enable improved understanding and management of the nuances in adopting RMS. 


\section{References}

Abbasi, M. 2017. Towards socially sustainable supply chains-themes and challenges. European Business Review 29 (3):261-303. doi:10.1108/EBR-03-2016-0045.

Achrol, R.S and P. Kotler. 1999. Marketing in the Network Economy. Journal of Marketing. 63 (4):146-63. doi:10.2307/1252108.

Achrol, R. S., T. Reve, and L. W. Stern. 1983. The environment of marketing channel dyads: a framework for comparative analysis. The Journal of Marketing 47 (4): 55-67. doi: $10.2307 / 1251399$.

Addo-Tenkorang, R., and P.T. Helo. 2017. Analysis of enterprise supply chain communication networks in engineering product development. The International Journal of Logistics Management 28 (1):47-74. doi:10.1108/IJLM-12-2014-0204.

Alvarez, G., C. Pilbeam, and R. Wilding. 2010. Nestlé Nespresso AAA sustainable quality program: an investigation into the governance dynamics in a multi-stakeholder supply chain network. Supply Chain Management: An International Journal 15 (2):165-182. doi: $\underline{10.1108 / 13598541011028769 .}$.

Anderson, J.C., Håkansson, H., and Johanson, J. 1994. Dyadic business relationships within a business network context. The Journal of Marketing 58 (4):1-15. doi:10.2307/1251912.

Andersen, M., and T. Skjoett-Larsen. 2009. Corporate social responsibility in global supply chains. Supply Chain Management: An International Journal 14 (2):75-86. doi: $\underline{10.1108 / 13598540910941948 .}$.

Araujo, L., and D. Harrison. 2002. Path dependence, agency and technological evolution. Technology Analysis and Strategic Management 14 (1):5-19. doi: $\underline{10.1080 / 09537320220125856 .}$.

Aßländer, M.S., J. Roloff, and D.Z. Nayır. 2016. Suppliers as stewards? Managing social standards in first-and second-tier suppliers. Journal of Business Ethics 139 (4):661-683. doi:10.1007/s10551-016-3148-0.

Awaysheh, A., and R.D. Klassen. 2010. The impact of supply chain structure on the use of supplier socially responsible practices. International Journal of Operations and Production Management 30 (12):1246-1268. doi:10.1108/01443571011094253.

Bandara, S., C. Leckie, A. Lobo, and C. Hewege. 2017. Power and relationship quality in supply chains: the case of the Australian organic fruit and vegetable industry. Asia Pacific Journal of Marketing and Logistics 29 (3):501-518. doi:10.1108/APJML-09-2016-0165.

Bellamy, M.A., and R.C. Basole. 2013. Network analysis of supply chain systems: a systematic review and future research. Systems Engineering 16 (2):235-249. doi:10.1002/sys.21238.

Bellamy, M.A., S. Ghosh, and M. Hora. 2014. The influence of supply network structure on firm innovation. Journal of Operations Management 32 (6):357-373. doi: 10.1016/j.jom.2014.06.004. 
Beske-Janssen, P., M.P. Johnson, and S. Schaltegger. 2015. 20 years of performance measurement in sustainable supply chain management-what has been achieved?. Supply Chain Management: An International Journal 20 (6):664-680. doi:10.1108/SCM-06-2015-0216.

Betts, T.K., F. Wiengarten, and S.K. Tadisina. 2015. Exploring the impact of stakeholder pressure on environmental management strategies at the plant level: what does industry have to do with it?. Journal of Cleaner Production 92 :282-294. doi: 10.1016/j.jclepro.2015.01.002.

Boyle, B., F.R. Dwyer, R.A. Robicheaux, and J.T. Simpson. 1992. Influence strategies in marketing channels: measures and use in different relationship structures. Journal of Marketing Research 29 (4):462-473. doi:10.2307/3172712.

Braziotis, C., M. Bourlakis, H. Rogers, and J. Tannock. 2013. Supply chains and supply networks: distinctions and overlaps. Supply Chain Management: An International Journal 18 (6):644-652. doi:10.1108/SCM-07-2012-0260.

Bridges, C.M., and W.B. Wilhelm. 2008. Going beyond green: The "why and how" of integrating sustainability into the marketing curriculum. Journal of Marketing Education 30 (1):33-46. doi:10.1177/0273475307312196.Busse, C., M.C. Schleper, J. Weilenmann, and S.M. Wagner. 2017. Extending the supply chain visibility boundary: utilizing stakeholders for identifying supply chain sustainability risks. International Journal of Physical Distribution and Logistics Management 47 (1):18-40. doi:10.1108/IJPDLM-02-2015-0043.

Caridi, M., L. Crippa, A. Perego, A. Sianesi, and A. Tumino. 2010. Do virtuality and complexity affect supply chain visibility?. International Journal of Production Economics 127 (2):372-383. doi:10.1016/j.ijpe.2009.08.016.

Carter, C.R., D.S. Rogers, and T.Y. Choi. 2015. Toward the theory of the supply chain. Journal of Supply Chain Management 51 (2):89-97. doi:10.1111/jscm.12073.

Chang, C.W., D.M. Chiang, and F.Y. Pai. 2012. Cooperative strategy in supply chain networks. Industrial Marketing Management 41 (7):1114-1124. doi:10.1016/j.indmarman.2012.04.011.

Cheng, C., and E. Holmen. 2015. Relationship and networking strategy tools: characterizing the IMP toolbox. IMP Journal 9 (2):177-207. doi:10.1108/IMP-03-2015-0013.

Chu, P.Y., K.H. Chang, and H.F. Huang. 2011. The role of social mechanisms in promoting supplier flexibility. Journal of Business-to-Business Marketing 18 (2):155-187. doi:10.1080/1051712X.2010.499835.

Ciliberti, F., G.d. Groot, J.d. Haan, and P. Pontrandolfo. 2009. Codes to coordinate supply chains: SMEs' experiences with SA8000. Supply Chain Management: An International Journal 14 (2):117-127. doi:10.1108/13598540910941984.

Connelly, B.L., D.J. Ketchen, and S.F. Slater. 2011. Toward a "theoretical toolbox" for sustainability research in marketing. Journal of the Academy of Marketing Science 39 (1):86100. doi: 10.1007/s11747-010-0199-0. 
Crespin-Mazet, F., and E. Dontenwill. 2012. Sustainable procurement: building legitimacy in the supply network. Journal of Purchasing and Supply Management 18 (4):207-217. doi:10.1016/j.pursup.2012.01.002.

Cui, A.S., R.J. Calantone, and D.A. Griffith. 2011. Strategic change and termination of interfirm partnerships. Strategic Management Journal 32 (4):402-423. doi:10.1002/smj.881.

Dahlquist, S.H. and D.A. Griffith. 2015. A framework for the formation of governance portfolios in international interfirm marketing collaborations. AMS Review 5 (1-2):45-59. doi:10.1007/s13162-015-0065-9.Daugherty, P.J. 2011. Review of logistics and supply chain relationship literature and suggested research agenda. International Journal of Physical Distribution \& Logistics Management 41 (1):16-31. doi:10.1108/09600031111101402.

Dwyer, F.R., and O.C. Walker. 1981. Bargaining in an asymmetrical power structure. The Journal of Marketing 45 (1):104-115. doi:10.2307/1251724.

Dwyer, F.R., P.H. Schurr, and S. Oh. 1987. Developing buyer-seller relationships. The Journal of Marketing 51 (2):11-27. doi:10.2307/1251126.

Delmas, M., and I. Montiel. 2009. Greening the supply chain: when is customer pressure effective?. Journal of Economics and Management Strategy 18 (1):171-201. doi:10.1111/j.1530-9134.2009.00211.x.

Dixit, A.K., and B.J. Nalebuff. 1993. Thinking strategically: the competitive edge in business, politics, and everyday life. WW Norton and Company, New York.

Drucker, P.F., and J.L. Noel. 1986. Innovation and entrepreneurship: practices and principles. The Journal of Continuing Higher Education 34 (1):22-23. doi: $10.1080 / 07377366.1986 .10401060$.

Dubey, R., A. Gunasekaran, and T. Papadopoulos. 2017. Green supply chain management: theoretical framework and further research directions. Benchmarking: An International Journal 24 (1):184-218. doi:10.1108/BIJ-01-2016-0011.

Dubey, R., A. Gunasekaran, and T. Papadopoulos, T. Childe, S.J. Shibin, and S.F. Wamba. 2017. Sustainable supply chain management: framework and further research directions. Journal of Cleaner Production 142 (1):1119-1130. doi:10.1016/j.jclepro.2016.03.117.

Egels-Zandén, N., K. Hulthén, and G. Wulff. 2015. Trade-offs in supply chain transparency: the case of Nudie Jeans Co. Journal of Cleaner Production 107 :95-104. doi:10.1016/j.jclepro.2014.04.074.

Ekanayake, S., P. Childerhouse, and P. Sun. 2017. The symbiotic existence of interorganizational and interpersonal ties in supply chain collaboration. The International Journal of Logistics Management 28 (3):723-754. doi:10.1108/IJLM-12-2014-0198.

Emerson, R.M. 1962. Power-dependence relations. American Sociological Review 27 (1), 3141. doi: $10.2307 / 2089716$. 
Esty, D., and A. Winston. 2009. Green to gold: how smart companies use environmental strategy to innovate, create value, and build competitive advantage. John Wiley and Sons, Hoboken.

Ferro, C., C. Padin, G. Svensson, J.C. Sosa Varela, and B. Wagner. 2017. Validating a framework of stakeholders in connection to business sustainability efforts in supply chains. Journal of Business and Industrial Marketing 32 (1):124-137. doi:10.1108/JBIM-12-2015$\underline{0253}$.

Frazier, G.L., 1983a. Interorganizational exchange behavior in marketing channels: a broadened perspective. The Journal of Marketing 47 (4):68-78. doi:10.2307/1251400.

Frazier, G.L. 1983b. On the measurement of interfirm power in channels of distribution. Journal of Marketing research 20 (2):158-166. doi:10.2307/3151682.

Frazier, G.L., E. Maltz, K.D. Antia, and A. Rindfleisch. 2009. Distributor sharing of strategic information with suppliers. Journal of Marketing 73 (4):31-43. doi:10.1509/jmkg.73.4.31.

Frazier, G.L., J.D. Gill, and S.H. Kale. 1989. Dealer dependence levels and reciprocal actions in a channel of distribution in a developing country. The Journal of Marketing 53 (1):50-69. doi: $10.2307 / 1251524$.

Frazier, G.L. and K.D. Antia. 1995. Exchange relationships and interfirm power in channels of distribution. Journal of the Academy of Marketing Science 23 (4):321-326. doi: $10.1177 / 009207039502300412$.

Frazier, G.L. and R.C. Rody. 1991. The use of influence strategies in interfirm relationships in industrial product channels. The Journal of Marketing 55 (1):52-69. doi:10.2307/1252203.

Frostenson, M., and F. Prenkert. 2015. Sustainable supply chain management when focal firms are complex: a network perspective. Journal of Cleaner Production 107 :85-94. doi:10.1016/j.jclepro.2014.05.034.

Geyskens, I., K. Gielens, and S. Wuyts. 2015. United we stand: the impact of buying groups on retailer productivity. Journal of Marketing 79 (4):16-33. doi:10.1509/jm.14.0202.

Ghosh, M. and G. John. 2012. Progress and prospects for governance value analysis in marketing: when Porter meets Williamson. Handbook on Business to Business Marketing.

Ghosh, M., and G. John. 2005. Strategic fit in industrial alliances: an empirical test of governance value analysis. Journal of Marketing Research 42 (3):346-357. doi: $\underline{10.1509 / \mathrm{jmkr} .2005 .42 .3 .346 .}$

Ghosh, M. and G. John. 2009. When should original equipment manufacturers use branded component contracts with suppliers?. Journal of Marketing Research 46 (5):597-611. doi:10.1509/jmkr.46.5.597.

Gilliland, D.I., D.C. Bello, and G.T. Gundlach. 2010. Control-based channel governance and relative dependence. Journal of the Academy of Marketing Science 38 (4):441-455. doi:10.1007/s11747-009-0183-8. 
Glover, J.L., D. Champion, K.J. Daniels, and A.J.D. Dainty. 2014. An institutional theory perspective on sustainable practices across the dairy supply chain. International Journal of Production Economics 152 (12):102-111. doi:10.1016/j.ijpe.2013.12.027.

Grewal, R., A. Saini, A. Kumar, F.R. Dwyer, and R. Dahlstrom. 2018. Marketing channel management by multinational corporations in foreign markets. Journal of Marketing 82 (4):4969. doi:10.1509/jm.16.0335.

Griffith, D.A. and B.V. Dimitrova. 2014. Business and cultural aspects of psychic distance and complementarity of capabilities in export relationships. Journal of International Marketing 22 (3):50-67. doi:10.1509/jim.14.0019.

Griffith, D.A., and H.S. Lee. 2016. Cross-national collaboration of marketing personnel within a multinational: leveraging customer participation for new product advantage. Journal of International Marketing 24 (4):1-19. doi:10.1509/jim.16.0028.

Griffith, D.A., J.J. Hoppner, H.S. Lee, and T. Schoenherr. 2017. The influence of the structure of interdependence on the response to inequity in buyer-supplier relationships. Journal of Marketing Research 54 (1):124-137. doi:10.1509/jmr.13.0319.

Griffith, D.A., and M.G. Harvey. 2004. The influence of individual and firm level social capital of marketing managers in a firm's global network. Journal of World Business 39 (3):244-254. doi:10.1016/j.jwb.2004.04.004.

Grimm, J.H., J.S. Hofstetter, and J. Sarkis. 2016. Exploring sub-suppliers' compliance with corporate sustainability standards. Journal of Cleaner Production 112 :1971-1984. doi:10.1016/j.jclepro.2014.11.036.

Gouda, S.K. and H. Saranga. 2018. Sustainable supply chains for supply chain sustainability: impact of sustainability efforts on supply chain risk. International Journal of Production Research. doi: 10.1080/00207543.2018.1456695.

Gualandris, J., and M. Pagell. 2015. Closing the accountability gap for sustainability: The aid comes from NGOs and their supply chains. in 75th Annual meeting of Academy of Management (conference proceedings). Retrieved August 24, 2015, from http://www.researchgate.net/publication/275716254_Closing_the_accountability_gap_for_su stainability the aid_comes_from_NGOs_and_their_supply_chains.

Gundlach, G.T., and E.R. Cadotte. 1994. Exchange interdependence and interfirm interaction: research in a simulated channel setting. Journal of Marketing Research 31 (4):516-532. doi: $\underline{10.2307 / 3151880 .}$.

Hannah, S.L., and A.D. Griffith. 2012. Transferring corporate brand image to local markets: governance decisions for market entry and global branding strategy. In K.S. Swan. and Z. Shaoming (ed.). Interdisciplinary Approaches to Product Design, Innovation, \& Branding in International Marketing (Advances in International Marketing). Emerald Group Publishing Limited. 23:39 - 65 . 
Harland, C.M., R.C. Lamming, J. Zheng, and T.E. Johnsen. 2001. A taxonomy of supply networks. Journal of Supply Chain Management 37 (3):21-27. doi:10.1111/j.1745493X.2001.tb00109.x.

Hartmann, J., and S. Moeller. 2014. Chain liability in multitier supply chains? responsibility attributions for unsustainable supplier behavior. Journal of Operations Management 32 (5):281-294. doi:10.1016/j.jom.2014.01.005.

Håkansson, H., and D. Ford. 2002. How should companies interact in business networks?. Journal of Business Research 55 (2):133-139. doi:10.1016/S0148-2963(00)00148-XHeal, G. 1998. Interpreting sustainability. Sustainability: Dynamics and Uncertainty, Springer, 3-22.

Hibbard, J.D., N. Kumar, and L.W. Stern. 2001. Examining the impact of destructive acts in marketing channels relationships. Journal of Marketing Research 38 (1):45-61. doi:10.1509/jmkr.38.1.45.18831.

Heide, J.B. 1994. Interorganizational governance in marketing channels. The Journal of Marketing 58 (1):71-85. doi:10.2307/1252252.

Heide, J.B., and G. John. 1988. The role of dependence balancing in safeguarding transactionspecific assets in conventional channels. Journal of Marketing 52 (1):20-35. doi: $10.2307 / 1251683$.

Hoejmose, S., J. Grosvold, and A. Millington. 2013. Socially responsible supply chains: power asymmetries and joint dependence. Supply Chain Management: An International Journal 18 (3):277-291. doi:10.1108/SCM-01-2012-0033.

Homburg, C., and S. Kuester. 2001. Towards an improved understanding of industrial buying behavior: determinants of the number of suppliers. Journal of Business-to-Business Marketing 8 (2):5-33. doi: 10.1300/J033v08n02_03.

Houston, M.B., and S.A. Johnson. 2000. Buyer-supplier contracts versus joint ventures: determinants and conse- quences of transaction structure. Journal of Marketing Research 37 (1):1-15. doi:10.1509/jmkr.37.1.1.18719.

Hutt, M.D., P.H. Reingen, and J.R. Ronchetto Jr. 1988. Tracing emergent processes in marketing strategy formation. The Journal of Marketing 52 (1):4-19. doi:10.2307/1251682.

Huxham, C., and N. Beech. 2008. Inter-organizational Power. Oxford University Press.

Jin, Y., and P. Edmunds. 2015. Achieving a competitive supply chain network for a manufacturer: a resource-based approach. Journal of Manufacturing Technology Management 26 (5):744-762. doi:10.1108/JMTM-01-2013-0004.

John, G., 2017. Designing price contracts for procurement and marketing of industrial equipment. In Review of Marketing Research:203-220. Routledge. London.

John, G., A.M. Weiss, and S. Dutta. 1999. Marketing in technology-intensive markets: toward a conceptual framework. The Journal of Marketing 63 (special issue):78-91. doi: $\underline{10.2307 / 1252103 .}$. 
Johnsen, R.E., and S. Lacoste. 2016. An exploration of the 'dark side'associations of conflict, power and dependence in customer-supplier relationships. Industrial Marketing Management 59 (1):76-95. doi:10.1016/j.indmarman.2015.12.011.

Jorge, T.F., and D.B.J. Jerónimo. 2017. Supply chain integration and performance relationship: a moderating effects review. The International Journal of Logistics Management 28 (4):12431271. doi:10.1108/IJLM-02-2016-0043.

Kähkönen, A.K. 2014. The influence of power position on the depth of collaboration. Supply Chain Management: An International Journal 19 (1):17-30. doi:10.1108/SCM-03-2013-0079.

Kaneberg, E., S. Hertz, and L.M. Jensen. 2016. Emergency preparedness planning in developed countries: the Swedish case. Journal of Humanitarian Logistics and Supply Chain Management 6 (2):145-172. doi:10.1108/JHLSCM-10-2015-0039.

Kilduff, M., and W. Tsai. 2003. Social networks and organisations. London. Sage publication.

Kim, Y., T.Y. Choi, T. Yan, and K. Dooley. 2011. Structural investigation of supply networks: a social network analysis approach. Journal of Operations Management 29 (3):194-211. doi:10.1016/j.jom.2010.11.001.

Kishore, S., R.S. Rao, O. Narasimhan, and G. John. 2013. Bonuses versus commissions: a field study. Journal of Marketing Research 50 (3):317-333. doi:10.1509/jmr.11.0485.

Kotler, P. 2011. Reinventing marketing to manage the environmental imperative. Journal of Marketing 75 (4): 132-135. doi:10.1509/jmkg.75.4.132.

Kraljic, P. 1983. Purchasing must become supply management. Harvard Business Review 61 (5):109-117.

Kumar, A., J.B. Heide, and K.H. Wathne. 2011. Performance implications of mismatched governance regimes across external and internal relationships. Journal of Marketing 75 (2):117. doi:10.1509/jmkg.75.2.1.

Kumar, D., and C.P. Garg. 2017. Evaluating sustainable supply chain indicators using Fuzzy AHP: case of Indian automotive industry. Benchmarking: An International Journal 24 (6):1742-1766. doi:10.1108/BIJ-11-2015-0111.

Kumar, N., L.K. Scheer, and J.B.E.M. Steenkamp. 1995. The effects of perceived interdependence on dealer attitudes. Journal of Marketing Research 32 (3):348-356. doi: $10.2307 / 3151986$.

Lamming, R., T. Johnsen, J. Zheng, and C. Harland. 2000. An initial classification of supply networks. International Journal of Operations and Production Management 20 (6):675-691. doi: $10.1108 / 01443570010321667$.

Lee, K.H., and R. Ball. 2003. Achieving sustainable corporate competitiveness: strategic link between top management's (green) commitment and corporate environmental strategy. Greener Management International 44:89-104. http://www.jstor.org/stable/greemanainte. 
Lichtenthal, J.D. 2004. Business buyer relationship management through seamless internet integration. Journal of Relationship Marketing 2 (3-4):67-83. doi:10.1300/J366v02n03_05.

Lichtenthal, J.D., and S. Eliaz. 2003. Internet integration in business marketing tactics. Industrial Marketing Management 32 (1):3-13. doi:10.1016/S0019-8501(01)00198-5.

Liu, A.H., M. Bui, and M. Leach. 2013. Considering technological impacts when selecting food suppliers: comparing retailers' buying behavior in the United States and Europe. Journal of Business-to-Business Marketing 20 (2):81-98. doi:10.1080/1051712X.2012.750183.

Lukas, B.A., G.J. Whitwell, and J.B. Heide. 2013. Why do customers get more than they need? How organizational culture shapes product capability decisions. Journal of Marketing 77 (1):112. doi: $10.1509 / \mathrm{jm} .10 .0182$.

Lusch, R.F., and J.R. Brown. 1996. Interdependency, contracting, and relational behavior in marketing channels. Journal of Marketing 60 (4):19-38. doi:10.2307/1251899.

MacCarthy, B.L., and P. Jayarathne. 2012. Sustainable collaborative supply networks in the international clothing industry: a comparative analysis of two retailers. Production Planning and Control 23 (4):252-268. doi:10.1080/09537287.2011.627655.

Maloni, M., and W. Benton. 2000. Power influences in the supply chain. Journal of Business Logistics 21 (1):49-73.

Mares, R. 2010. The limits of supply chain responsibility: a critical analysis of corporate responsibility instruments. Nordic Journal of International Law 79 (2):193-244. doi:10.1163/157181010X12668401898995.

Mariadoss, B.J., P.S. Tansuhaj, and N. Mouri. 2011. Marketing capabilities and innovationbased strategies for environmental sustainability: an exploratory investigation of B2B firms. Industrial Marketing Management $40 \quad$ (8):1305-1318. doi:10.1016/j.indmarman.2011.10.006.Matthews, L., D. Power, A. Touboulic, and L. Marques. 2016. Building bridges: toward alternative theory of sustainable supply chain management. Journal of Supply Chain Management 52 (1):82-94. doi:10.1111/jscm.12097.

Meinlschmidt, J., M.C. Schleper, and K. Foerstl. 2018. Tackling the sustainability iceberg: a transaction cost economics approach to lower tier sustainability management. International Journal of Operations \& Production Management. In press. doi:10.1108/IJOPM-03-2017$\underline{0141 .}$

Mena, C., A. Humphries, and T.Y. Choi. 2013. Toward a theory of multi-tier supply chain management. Journal of Supply Chain Management 49 (2):58-77. doi: 10.1111/jscm.12003.

Meqdadi, O., T.E. Johnsen, and R.E. Johnsen. 2016. The role of power and trust in spreading sustainability initiatives across supply networks: a case study in the bio-chemical industry. Industrial Marketing Management. In press. doi:10.1016/j.indmarman.2016.06.006. 
Melander, L., D. Rosell, and N. Lakemond. 2014. In pursuit of control: involving suppliers of critical technologies in new product development. Supply Chain Management: An International Journal 19 (5/6):722-732. doi:10.1108/SCM-01-2014-0040.

Min, H., and W.P. Galle. 2001. Green purchasing practices of US firms. International Journal of Operations and Production Management 21 (9):1222-1238. doi:10.1108/EUM0000000005923.

Mysen, T., G. Svensson, and N. Högevold. 2012. Relationship quality-relationship value and power balance in business relationships: descriptives and propositions. Journal of Business-toBusiness Marketing 19 (3):248-285. doi:10.1080/1051712X.2012.638469.

Narasimhan, R., A. Nair, D.A. Griffith, J.S. Arlbjørn, and E. Bendoly. 2009. Lock-in situations in supply chains: a social exchange theoretic study of sourcing arrangements in buyer-supplier relationships. Journal of Operations Management 27 (5):374-389. doi:10.1016/j.jom.2008.10.004.

Neville, B.A., and B. Menguc. 2006. Stakeholder multiplicity: toward an understanding of the interactions between stakeholders. Journal of Business Ethics 66 (4):377-391. doi:10.1007/s10551-006-0015-4.

Pagano, A. 2008. Building supply chain excellence in emerging economies. Journal of business-to-business marketing 15 (3):354-363. doi:10.1080/15470620802059315.

Palmatier, R.W., L.K. Scheer, and J.B.E. Steenkamp. 2007. Customer loyalty to whom? Managing the benefits and risks of salesperson-owned loyalty. Journal of Marketing Research 44 (2):185-199. doi:10.1509/jmkr.44.2.185.

Parmigiani, A., R.D. Klassen, and M.V. Russo. 2011. Efficiency meets accountability: performance implications of supply chain configuration, control, and capabilities. Journal of Operations Management 29 (3):212-223. doi:10.1016/j.jom.2011.01.001.

Parris, D.L., J.L. Dapko, R.W. Arnold, and D. Arnold. 2016. Exploring transparency: a new framework for responsible business management. Management Decision 54 (1):222-247. doi:10.1108/MD-07-2015-0279.

Paulraj, A., and C. Blome. 2017. Plurality in environmental supply chain mechanisms: differential effects on triple bottom line outcomes. International Journal of Operations and Production Management 37 (8):1010-1030. doi:10.1108/IJOPM-11-2015-0722.

Peters, N. 2010), Inter-organisational design of voluntary sustainability initiatives, Gabler, Wiesbaden.

Pilbeam, C., G. Alvarez, and H. Wilson. 2012. The governance of supply networks: a systematic literature review. Supply Chain Management: An International Journal 17 (4):358376. doi:10.1108/13598541211246512.

Prince, M., D. Palihawadana, M.A.P. Davies, and R.D. Winsor. 2016. An integrative framework of buyer-supplier negative relationship quality and dysfunctional interfirm conflict. 
Provan, K.G., A. Fish, and J. Sydow. 2007. Interorganizational networks at the network level: a review of the empirical literature on whole networks. Journal of Management 33 (3):479516. doi:10.1177/0149206307302554.

Pullman, M., and R. Wikoff. 2017. Institutional sustainable purchasing priorities: stakeholder perceptions vs environmental reality. International Journal of Operations and Production Management 37 (2):162-181. doi:10.1108/IJOPM-07-2014-0348.

Rauer, J., and L. Kaufmann. 2015. Mitigating external barriers to implementing green supply chain management: a grounded theory investigation of green-tech companies' rare earth metals supply chains. Journal of Supply Chain Management 51 (2):65-88. doi:10.1111/jscm.12063.

Reve, T., and L.W. Stern. 1979. Interorganizational relations in marketing channels. Academy of Management Review 4 (3):405-416. doi:10.5465/amr.1979.4289111.

Ritter, T., I.F. Wilkinson, and W.J. Johnston. 2004. Managing in complex business networks. Industrial Marketing Management 33 (3):175-183. doi:10.1016/j.indmarman.2003.10.016.

Roberts, S. 2003. Supply chain specific? Understanding the patchy success of ethical sourcing initiatives. Journal of Business Ethics 44 (2/3):159-70. doi:10.1023/A:1023395631811.

Roome, N. 2001. Conceptualizing and studying the contribution of networks in environmental management and sustainable development. Business Strategy and the Environment 10 (2):6976. doi: $\underline{10.1002 / b s e .276 .}$

Roscoe, S., P.D. Cousins, and R.C. Lamming. 2016. Developing eco-innovations: a three-stage typology of supply networks. Journal of Cleaner Production 112):1948-1959. doi:10.1016/j.jclepro.2015.06.125.

Rowley, T.J. 1997. Moving beyond dyadic ties: a network theory of stakeholder influences. Academy of Management Review 22 (4):887-910. doi:10.5465/amr.1997.9711022107.

Sa Vinhas, A., and J.B. Heide. 2014. Forms of competition and outcomes in dual distribution channels: the distributor's perspective. Marketing Science 34 (1):160-175. doi: $10.1287 / \mathrm{mksc} .2014 .0880$.

Salonen, A. and Gabrielsson, M., 2012. The challenge of multinational corporation (MNC)-led growth and internationalization: the case of Nokia-dependent suppliers. Journal of Businessto-Business Marketing 19 (2):147-173. doi:10.1080/1051712X.2012.621848.

Sarkis, J., Q. Zhu, and K.h. Lai. 2011. An organizational theoretic review of green supply chain management literature. International Journal of Production Economics 130 (1):1-15. doi:10.1016/j.ijpe.2010.11.010.

Scheer, L.K., C.F. Miao, and J. Garrett. 2010. The effects of supplier capabilities on industrial customers' loyalty: the role of dependence. Journal of the Academy of Marketing Science 38 (1):90-104. doi:10.1007/s11747-008-0129-6. 
Scheer, L.K., C.F. Miao, and R.W. Palmatier. 2015. Dependence and interdependence in marketing relationships: meta-analytic insights. Journal of the Academy of Marketing Science 43 (6):694-712. doi:10.1007/s11747-014-0418-1.

Schneider, L., and C.M. Wallenburg. 2012. Implementing sustainable sourcing-does purchasing need to change?. Journal of Purchasing and Supply Management 18 (4):243-257. doi:10.1016/j.pursup.2012.03.002.

Seuring, S. 2011. Supply chain management for sustainable products-insights from research applying mixed methodologies. Business strategy and the Environment 20 (7):471-484. doi:10.1002/bse.702.

Seuring, S., and M. Müller. 2008. From a literature review to a conceptual framework for sustainable supply chain management. Journal of Cleaner Production 16 (15):1699-1710. doi: 10.1016/j.jclepro.2008.04.020.

Sharma, A., G.R. Iyer A. Mehrotra, and R. Krishnan. 2010. Sustainability and business-tobusiness marketing: a framework and implications. Industrial Marketing Management 39 (2):330-341. doi:10.1016/j.indmarman.2008.11.005.

Shokri Kahi, V., S. Yousefi, H. Shabanpour, and R. Farzipoor Saen. 2017. How to evaluate sustainability of supply chains? A dynamic network DEA approach. Industrial Management and Data Systems 117 (9):1866-1889. doi:10.1108/IMDS-09-2016-0389.

Simpson, D., D. Power, and R. Klassen. 2012. When one size does not fit all: a problem of fit rather than failure for voluntary management standards. Journal of Business Ethics 110 (1):8595. doi:10.1007/s10551-011-1149-6.

Snehota, I., and H. Hakansson. 1995. Developing relationships in business networks. Routledge London.

Soosay, C.A., and P. Hyland. 2015. A decade of supply chain collaboration and directions for future research. Supply Chain Management: An International Journal 20 (6):613-630. doi:10.1108/SCM-06-2015-0217.

Srinivasan, R., S. Wuyts, and G. Mallapragada. 2018. Corporate board interlocks and new product introductions. Journal of Marketing 82 (1):132-148. doi:10.1509/jm.16.0120.

Steinle, C., H. Schiele, and T. Ernst. 2014. Information asymmetries as antecedents of opportunism in buyer-supplier relationships: testing principal-agent theory. Journal of Business-to-Business Marketing 21 (2):123-140. doi:10.1080/1051712X.2014.903457.

Svensson, G., N. Høgevold, C. Ferro, J.C.S. Varela, C. Padin, and B. Wagner. 2016. A triple bottom line dominant logic for business sustainability: framework and empirical findings. Journal of Business-to-Business Marketing 23 (2):153-188. doi:10.1080/1051712X.2016.1169119. 
Tachizawa, E.M., and C.Y. Wong. 2014. Towards a theory of multi-tier sustainable supply chains: a systematic literature review. Supply Chain Management: An International Journal 19 (5/6):643-663. doi:10.1108/SCM-02-2014-0070.

Tihanyi, L., D.A. Griffith, and C.J. Russell. 2005. The effect of cultural distance on entry mode choice, international diversification, and MNE performance: a meta-analysis. Journal of International Business Studies 36 (3):270-283. doi:10.1057/palgrave.jibs.8400136.

Touboulic, A., D. Chicksand, and H. Walker. 2014. Managing imbalanced supply chain relationships for sustainability: a power perspective. Decision Sciences 45 (4):577-619. doi:10.1111/deci.12087.

Touboulic, A., and H.L. Walker. 2015. Theories in sustainable supply chain management: a structured literature review. International Journal of Physical Distribution and Logistics Management 45 (1/2):16-42. doi:10.1108/IJPDLM-05-2013-0106.

Tracey, P., J.B. Heide, and S.J. Bell. 2014. Bringing "place” back in: regional clusters, project governance, and new product outcomes. Journal of Marketing 78 (6):1-16. doi: 10.1509/jm.13.0524.

Turcu, C., A. Graur, and C. Turcu. 2009. Improvement of supply chain performances using RFID technology. INTECH Open Access Publisher, Croatia.

Vachon, S., and R.D. Klassen. 2006. Extending green practices across the supply chain: the impact of upstream and downstream integration. International Journal of Operations and Production Management 26 (7):795-821. doi:10.1108/01443570610672248.

Van den Bulte, C. 2011. Opportunities and challenges in studying customer networks. In the connected customer. Routledge. London.

Van den Bulte, C., and S.H.K. Wuyts. 2007. Social networks in marketing. Cambridge. Marketing Science Institute.

Vurro, C., A. Russo, and F. Perrini. 2009. Shaping sustainable value chains: network determinants of supply chain governance models. Journal of Business Ethics 90 (4):607-621. doi: $10.1007 / \mathrm{s} 10551-010-0595-\mathrm{X}$.

Walker, H., L. D. Sisto, and D. McBain. 2008. Drivers and barriers to environmental supply chain management practices: lessons from the public and private sectors. Journal of Purchasing and Supply Management 14 (1):69-85. doi: 10.1016/j.pursup.2008.01.007.

Wathne, K.H. and J.B. Heide. 2000. Opportunism in interfirm relationships: forms, outcomes, and solutions. Journal of Marketing 64 (4):36-51. doi:10.1509/jmkg.64.4.36.18070.

Wathne, K.H. and J.B. Heide. 2004. Relationship governance in a supply chain network. Journal of Marketing 68 (1):73-89. doi:10.1509/jmkg.68.1.73.24037.

Wathne, K.H., J.B. Heide, E.A. Mooi, and A. Kumar. 2018. Relationship governance dynamics: the role of partner selection efforts and mutual investments. Journal of Marketing Research. In press. doi:10.1509/jmr.15.0505. 
Watson IV, G.F., S. Weaven, H. Perkins, D. Sardana, and R.W. Palmatier. 2018. International market entry strategies: relational, digital, and hybrid approaches. Journal of International Marketing 26 (1):30-60. doi:10.1509/jim.17.0034.

Wichmann, B.K., and L. Kaufmann. 2016. Social network analysis in supply chain management research. International Journal of Physical Distribution and Logistics Management 46 (8):740-762. doi:10.1108/IJPDLM-05-2015-0122.

Wilhelm, M.M., C. Blome, V. Bhakoo, and A. Paulraj. 2016a. Sustainability in multi-tier supply chains: understanding the double agency role of the first-tier supplier. Journal of operations management 41(1):42-60. doi:10.1016/j.jom.2015.11.001.

Wilhelm, M.M., C. Blome, E. Wieck, and C.Y. Xiao. 2016b. Implementing sustainability in multi-tier supply chains: strategies and contingencies in managing sub-suppliers. International Journal of Production Economics 182 (1):196-212. doi:10.1016/j.ijpe.2016.08.006.

Winkler, H. 2011. Closed-loop production systems: a sustainable supply chain approach. CIRP Journal of Manufacturing Science and Technology 4 (3):243-246. doi:10.1016/j.cirpj.2011.05.001.

Wognum, P.N., H. Bremmers, J.H. Trienekens, J.G. van der Vorst, and J.M. Bloemhof. 2011. Systems for sustainability and transparency of food supply chains-current status and challenges. Advanced Engineering Informatics 25 (1):65-76. doi:10.1016/j.aei.2010.06.001.

Wolf, J. 2014. The relationship between sustainable supply chain management, stakeholder pressure and corporate sustainability performance, Journal of Business Ethics 119 (3):317-328. doi:10.1007/s10551-012-1603-0.

Wuyts, S., and C. Van den Bulte. 2012. Network Governance. In: Lilien, G.L., and R. Grewal. (eds.). Handbook of Business-to-Business Marketing. Cheltenham. UK: Edgar Elgar.

Wuyts, S., and I. Geyskens. 2005. The formation of buyer-supplier relationships: detailed contract drafting and close partner selection. Journal of Marketing 69 (4):103-117. doi:10.1509/jmkg.2005.69.4.103.

Wuyts, S., and S. Dutta. 2014. Benefiting from alliance portfolio diversity: the role of past internal knowledge creation strategy. Journal of Management. 40 (6):1653-1674. doi: $10.1177 / 0149206312442339$.

Wuyts, S., S. Dutta, and S. Stremersch. 2004. Portfolios of interfirm agreements in technologyintensive markets: consequences for innovation and profitability. Journal of Marketing 68 (2):88-100. doi:10.1509/jmkg.68.2.88.27787.

Zhang, J.Z., G.F. Watson IV, R.W. Palmatier, and R.P. Dant. 2016. Dynamic relationship marketing. Journal of Marketing 80 (5):53-75. doi:10.1509/jm.15.0066.

Zhang, M., K.S. Pawar, and S. Bhardwaj. 2017. Improving supply chain social responsibility through supplier development. Production Planning \& Control 28 (6-8):500-511. doi:10.1080/09537287.2017.1309717. 